\title{
Vitamin K in Vertebrates' Reproduction: Further Puzzling Pieces of Evidence from Teleost Fish Species
}

\author{
Silvia Beato ${ }^{1} \mathbb{C}$, Francisco Javier Toledo-Solís ${ }^{2,3}{ }^{\mathbb{D}}$ and Ignacio Fernández ${ }^{4, *}$ \\ 1 Campus de Vegazana, s/n, Universidad de León (ULE), 24071 León, Spain; silviabeato@hotmail.it \\ 2 Consejo Nacional de Ciencia y Tecnología (CONACYT, México), Av. Insurgentes Sur 1582, Col. Crédito \\ Constructor, Alcaldía Benito Juárez, C.P. 03940 Ciudad de Mexico, Mexico; fj.toledos@gmail.com \\ 3 Department of Biology and Geology, University of Almería, 04120 Almería, Spain \\ 4 Center for Aquaculture Research, Agrarian Technological Institute of Castile and Leon, Ctra. Arévalo, s/n, \\ 40196 Zamarramala, Segovia, Spain \\ * Correspondence: nacfm@hotmail.com; Tel.: +34-921-412-716 (ext. 860 889)
}

Received: 20 July 2020; Accepted: 4 September 2020; Published: 9 September 2020

\begin{abstract}
Vitamin $\mathrm{K}(\mathrm{VK})$ is a fat-soluble vitamin that vertebrates have to acquire from the diet, since they are not able to de novo synthesize it. VK has been historically known to be required for the control of blood coagulation, and more recently, bone development and homeostasis. Our understanding of the VK metabolism and the VK-related molecular pathways has been also increased, and the two main VK-related pathways-the pregnane $X$ receptor (PXR) transactivation and the co-factor role on the $\gamma$-glutamyl carboxylation of the VK dependent proteins-have been thoroughly investigated during the last decades. Although several studies evidenced how VK may have a broader VK biological function than previously thought, including the reproduction, little is known about the specific molecular pathways. In vertebrates, sex differentiation and gametogenesis are tightly regulated processes through a highly complex molecular, cellular and tissue crosstalk. Here, VK metabolism and related pathways, as well as how gametogenesis might be impacted by VK nutritional status, will be reviewed. Critical knowledge gaps and future perspectives on how the different VK-related pathways come into play on vertebrate's reproduction will be identified and proposed. The present review will pave the research progress to warrant a successful reproductive status through VK nutritional interventions as well as towards the establishment of reliable biomarkers for determining proper nutritional VK status in vertebrates.
\end{abstract}

Keywords: K vitamers; steroid X receptor; vitamin K epoxide reductase; hypothalamus-pituitarygonad axis; exosomes; non-coding RNAs; microRNAs; piRNAs

\section{Vitamin K Metabolites, Sources and Metabolism}

Fat-soluble vitamins, including vitamin A, D, E, and K, are essential micronutrients for vertebrate's development. In general, fat-soluble vitamins have a relatively heterogenic chemical structure, with most of them being terpenes or containing long terpene chains attached to an aromatic moiety. The exception is vitamin D (VD), which has a triene moiety instead of the aromatic one. Additionally, specific amounts and chemical forms of fat-soluble vitamins need to be provided in the diet, since these organic compounds cannot be endogenously synthesized by vertebrates, at least not in adequate amounts. Again, VD could be considered the exception. Although mammals are able to photoconvert 7-dehydrocholesterol into pre-vitamin D3 in the skin and only a minor supply is provided by the diet, no strong evidences of VD photosynthesis have been documented in fish species until now [1]. Furthermore, vitamin $\mathrm{K}(\mathrm{VK})$ can also be obtained from the intestinal microbiome, although the 
relevance of this contribution remains controversial [2]. Furthermore, no or low dietary toxicity was reported for VK in contrast to the other fat-soluble vitamins [1].

In general, three different VK metabolites (or K vitamers) can be found (Figure 1). All of them are derived from quinone, exhibiting a common 2-methyl-1,4-naphthoquinone ring, but differing in the side chain at the C3-position [3]. Phylloquinone (or VK1), produced by photosynthetic plants, and menaquinones (or VK2), with microbial or animal origin, are the known VK natural compounds [4,5]. Regarding menaquinones, more than 20 different metabolites have been described, named MK-n accordingly to the number (n) of prenyl groups in the unsaturated side chain, but MK-4 and MK-7 being the most relevant forms from a nutritional point of view [5]. Menadione (or VK3) is the third K vitamer, a synthetic water-soluble salt without side chain. Despite being known to induce oxidative stress [6], it is categorized as safe VK supplement in livestock [7]. In fact, VK3 is easily excreted and shows lower bioavailability than the naturally occurring K vitamers. Nevertheless, although it is the most commonly used source of VK included in animal feeds, VK3 needs to be metabolized in order to be functional.

(a)

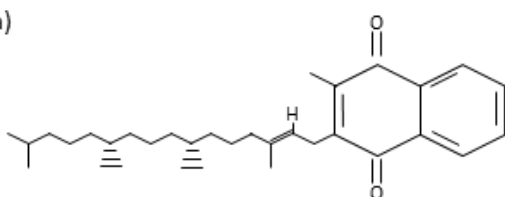

(c)

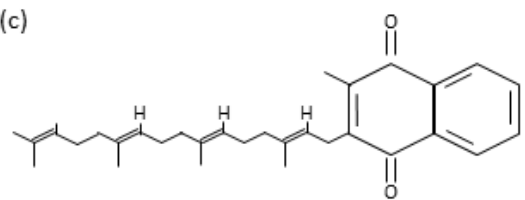

(b)

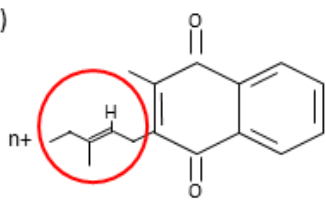

(e)<smiles>CC1=CC(=O)c2ccccc2C1=O</smiles>

(d)

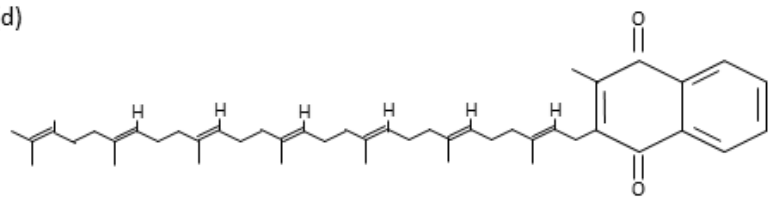

Figure 1. Main vitamin $\mathrm{K}$ metabolites. Phylloquinone (a), menaquinones, with the prenyl group highlighted with a red circle (b), menaquinone 4 (c), menaquinone 7 (d), and menadione (e).

All of the $\mathrm{K}$ vitamers from the diet can be absorbed at the intestine, including those that originated from the intestinal microbiome $[2,8]$. Recent studies unequivocally evidenced the involvement of scavenger receptor class B type I (SR-BI), cluster of differentiation 36 (CD36), and Niemann-Pick C1-like 1 (NPC1L1) transporters on the uptake of VK1 at the intestinal lumen (reviewed in [9]). VK is absorbed chemically unchanged from the lumen at the proximal intestine, with $80 \%$ absorption efficiency for VK1 on its free form. Indeed, VK1 is the major circulating form of VK, although other K vitamers have also been found in the blood plasma (e.g., VK3, MK-4, and MK-7; $[10,11])$. The presence of VK3 is presumably resulting from a side chain cleavage of VK1 that only seemed to occur during intestinal absorption [11,12]. Unbound VK3 in circulation is highly reactive and easily excreted, not remaining in blood for a long period. The subsequent prenylation of VK3 to MK-4 at the enterocytes [11] or any other tissues (including testis; [13]) has been suggested, a reaction that seems to be catalyzed by the ubiquitously expressed UbiA prenyltransferase domain-containing protein 1 (Ubiad1) $[8,14]$. Nevertheless, orally administered MK-4 and MK-7 can be also converted to MK-4 [8] and thus, the previously described metabolic transformations of a certain amount of VK1 might be also applied to other members of the VK family [9].

As long as the VK was only considered to be involved on the hepatic $\gamma$-carboxylation of clotting factors, the liver was considered to be the uniquely significant storage site of VK [15]. Nowadays, it is known that mammalian liver stores 90 and 10\% of menaquinones and phylloquinone [9], respectively. Other tissues/systems containing significant levels of $\mathrm{K}$ vitamers are blood plasma, adipose tissue, bone, heart, kidney, spleen, brain, ovaries and/or testes, being thyroid, adrenal, testes, ovaries, pancreas, salivary, and skin particularly enriched in MK-4 [9,16]. Such wide tissue distribution is consistent with the ubiquitous and evolutionary conserved expression of the main drivers of VK pathways (briefly 
described in the next subsection): the pregnane $X$ receptor ( $p x r$; also known as steroid $X$ receptor or sxr) [17-20] and the $\gamma$-glutamyl carboxylase ( $g g c x)$ [21,22]. Furthermore, MK-4 enriched distribution in particular tissues seemed to be determined by local synthesis of MK-4, rather than by its uptake [23]. In this sense, while VK1 is known to be preferentially retained in the liver to assist $\gamma$-carboxylation of clotting factors, where VK recycling is basically performed through VK epoxide reductase (VKOR) complex subunit 1 (VKORC1); VK2 have to be redistributed through circulation (or in situ converted) in order to be available for extra-hepatic tissues, where VK recycling could be more related to VKORC1-like protein 1 (VKORC1L1) [24]. Indeed, several studies suggested VK2 as being more effective in activating extra-hepatic VKDPs than VK1 [25]. Nevertheless, levels of each K vitamers at each tissue/system might depend on the considered vertebrate species, gender, population, and/or the daily dietary uptake $[1,16,26]$. Furthermore, a variable response to VK1 dietary supplementation in humans was recently associated to differences in DNA methylation in multiple genomic regions [27].

Because VK stores are very labile and rapidly respond through specific pathways to nutritional status (fasting/feeding/nutritional supplementation), as well as other conditions, such as pharmacological treatment with VK anticoagulants [2,16,20,28-31], an optimized daily VK dietary uptake is recommended [32,33]. This daily uptake may avoid VK deficiencies and their related pathological conditions. To fulfill VK nutritional requirements, an equilibrated intake of VK from diverse dietary sources and a healthy intestinal microbiota seems to be necessary [2]. Determining a general optimal dietary VK intake seemed to be pursuing a chimera, since a reliable golden standard biomarker of VK nutritional status is still lacking [33,34]. In this sense, identifying the biological functions that require VK is critical. Nowadays, VK is quite well known in vertebrates to be required for blood coagulation [35-37], skeletal and joint tissues [19,38-42], and pathological calcification and inflammation [37,43-45]. There are some reports on their potential role on redox homeostasis [41,46,47], sphingolipid [48,49] and glucose metabolism [50], neural development and cognitive capacities [20,48,51,52], as well as angiogenesis [53]. Furthermore, some evidences have been presented regarding the potential role of VK on the reproduction of mammalian $[54,55]$ and fish species $[37,49,55]$. Altogether, the idea of a well conserved function of VK along evolution is reinforced, including the related molecular pathways [56,57].

\section{Vitamin K Molecular Pathways}

In addition to its potential antioxidant function, VK may exert their biological functions by two different molecular pathways: acting as a co-factor of GGCX and transactivating the NR PXR. How VK might be up taken, metabolized, transported, and exert their effects at a transcriptional level or through the carboxylation of VKDPs in vertebrates is summarized in Figure 2, based on the most recent literature $[1,9,15,17,29,58-62]$.

GGCX is a transmembrane protein that is localized at the endoplasmic reticulum (ER) and it catalyzes the conversion of specific glutamate (Glu) residues to $\gamma$-carboxyglutamate (Gla) residues, a process called $\gamma$-carboxylation, where VK acts as a co-factor [62]. GGCX activity was detected in most or all mammalian tissues, and the carboxylase gene has been demonstrated to be evolutionarily conserved in other vertebrates, such as fish, but also in chordates (such as Ciona intestinalis) and invertebrates $[9,22,63-66]$. $\Gamma$-carboxylation is vital for the survival of vertebrates as mouse lacking GGCX die at birth due to fatal hemorrhages [35]. Indeed, as a co-factor of the GGCX enzyme, VK is essential for the activation and proper functioning of multiple proteins that are known as VK-dependent proteins (VKDPs). The most well-known VKDPs are those that are involved in blood clotting: coagulation factors (FII, FVII, FIX and FX) and natural anti-clotting agents (protein C, protein S and protein Z) [36]. However, GGCX also catalyzes $\gamma$-carboxylation of other VKDPs involved in various biological processes, such as inflammation (gla-rich protein (GRP)), bone formation (osteocalcin (OC; also known as bone Gla protein (BGP or BGLAP))), cell proliferation (growth arrest-specific 6 (GAS6)), and soft tissue mineralization (matrix Gla protein (MGP)) [36,67]. Of note, while VKDPs involved in blood coagulation are $\gamma$-carboxylated at the liver, the other VKDPs are $\gamma$-carboxylated in extra-hepatic 
tissues. An abnormal rate of $\gamma$-carboxylation at extra-hepatic tissues might have relevant physiological implications, from altered blood coagulation and skeletal development to impaired gametogenesis.

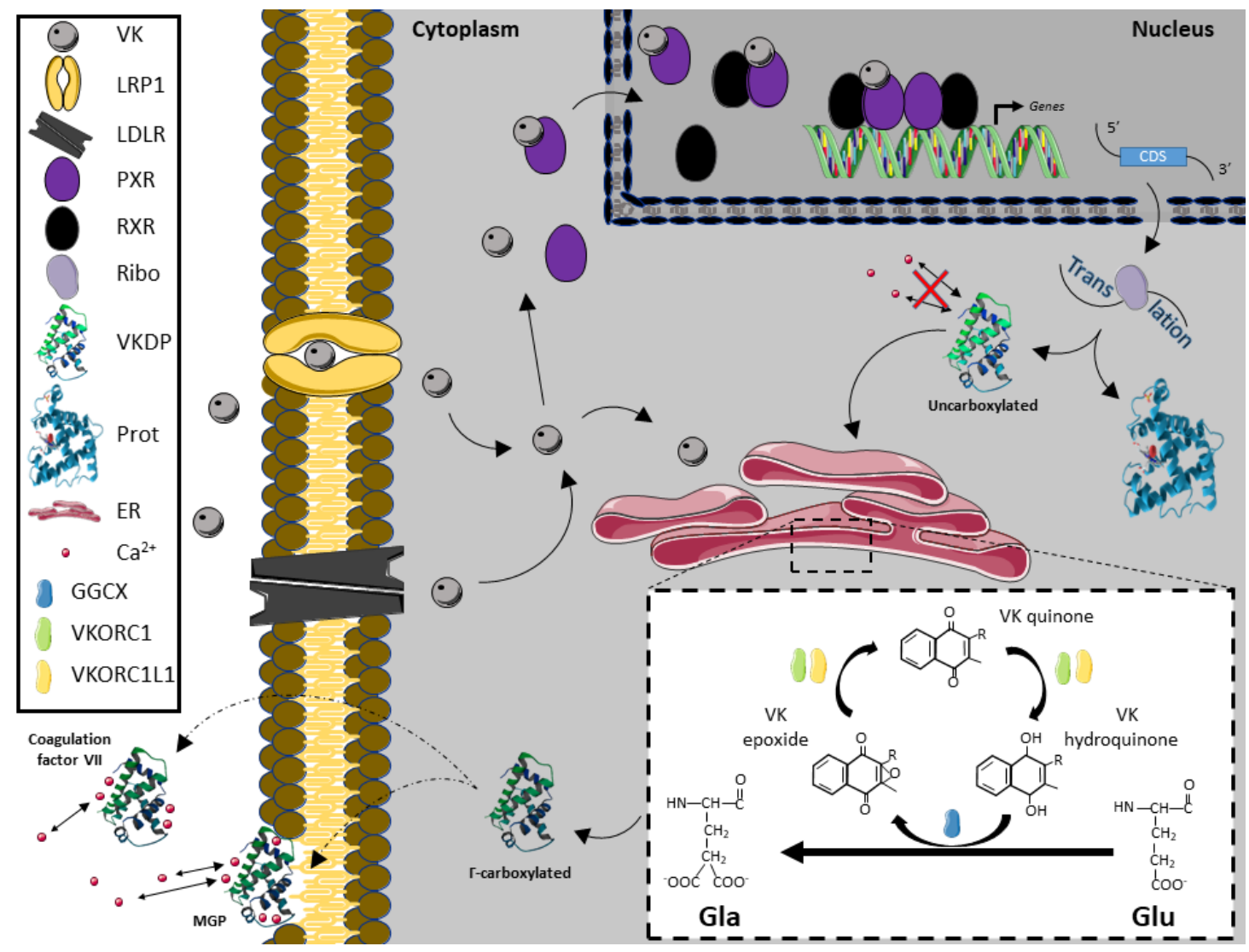

Figure 2. Vitamin K metabolic and transcriptional roles. Vitamin K (VK) enters cell cytoplasm through the action of low-density lipoprotein receptor (LDLR) and prolow-density lipoprotein receptor-related protein 1 (LRP1). VK might transactivate pregnane $X$ receptor (PXR), which in turn form an heterotetramer with the retinoid X receptor (RXR) able to be bound to the DNA RXR-PXR response element sequences and recruit co-activators and RNA polymerase II in order to transcribe the target genes. In this manner, PXR is able to activate the transcription of different genes, including known VK dependent proteins (VKDPs), as such MGP, among others. After genes encoding VKDPs are transcribed, mRNAs are translated to the corresponding proteins. VKDPs can undergo $\gamma$-carboxylation at the endoplasmic reticulum (ER), where VK (quinone form) is reduced to VK hydroquinone which acts as a co-factor of the $\gamma$-glutamyl carboxylase (GGCX) enzyme to $\gamma$-carboxylate those VKDPs. As a result of the conversion of Glu residues in Gla residues, VKDPs are able to bind calcium ions $\left(\mathrm{Ca}^{2+}\right)$ while VK hydroquinone is oxidated to VK epoxide. Both VK epoxide reductase complex subunint 1 (VKORC1) and VKORC1-like protein 1 (VKORC1L1) enzymes are able to reduce VK epoxide to VK quinone and VK quinone to VK hydroquinone; therefore recycling VK. CDS, coding sequence; $E R$, endoplasmic reticulum; GGCX, $\gamma$-glutamyl carboxylase; Gla, $\gamma$-carboxylated glutamic acid; Glu, glutamic acid; $L D L R$, low-density lipoprotein receptor; $L R P 1$, low-density lipoprotein receptor-related protein 1; MGP, matrix Gla protein; Prot, protein; $P X R$, pregnane $X$ receptor; Ribo, ribosomal subunits; $R X R$, retinoid $\mathrm{X}$ receptor; $V K$, vitamin $\mathrm{K} ; V K D P$, VK dependent protein; $V K O R C 1, \mathrm{VK}$ epoxide reductase complex subunit 1; VKORC1L1, VKORC1-like protein 1.

Carboxylation requires the abstraction of a proton from the four-carbon of the glutamate residue by reduced VK, which results in the conversion of VK into VK epoxide. The VK epoxide must be recycled, a reaction that is catalyzed by two VK 2,3-epoxide reductases (VKORs) [62]. VKORs are also transmembrane proteins that are localized at the ER, being essential for a continuous 
$\gamma$-carboxylation of VKDPs, and intimately connected to GGCX. Indeed, although VKORC1 knockout mice survive longer than $\mathrm{GGCX}^{-/}$mice, they exhibited early postnatal lethality due to severe bleeding [68], which suggests VK recycling is critical in sustaining $\gamma$-carboxylation of blood clotting factors. A well evolutionary conserved structure and function of VKORs has been suggested [57], where the VKORC1 and VKORC1L1 paralogs probably arose from the duplication of a VKOR ancestor gene [29-31,46,56,57,60,61]. A ubiquitous gene expression of both vkorc1 and vkorc1l1 genes in vertebrates has been reported [29-31,56,60,61]. In vertebrates, the highest vkorc1 expression is found in liver, consistent with being the main isoform that is responsible for recycling VK epoxide originated from hepatic $\gamma$-carboxylation of hemostasis-related VKDPs [60,61]. In contrast, highest vkorc1l1 gene expression in vertebrates was found in brain and ovaries, but also high expression levels were reported in organs, like kidney, eye, and testis $[31,56,58]$. Recent structural insights on how VKORC1 is preferentially binding to VK1 and MK4, rather than MK7 [69] pointed out further differences on VK recycling capacity, depending on the substrate (VK form) and the VKOR paralog (VKORC1 or VKORC1L1). The presence of VK metabolites, $\gamma$-carboxylation activity, and VK recycling in male and female gonads might be the first evidence suggesting that VK might be required in vertebrate's reproduction.

The other main pathway of the VK is the transactivation of the NR PXR [17]. PXR is a member of the NR super-family NR1I (NR1I2), including PXR, vitamin D receptor (VDR, NR1I1), and constitutive androstane receptor (CAR, NR1I3) [70]. Molecular phylogenies of the NR1I super-family suggested that VDR, PXR, and CAR sequentially evolved from a common ancestor represented by Ciona intestinalis VDR/PXR [20]. As a NR, PXR modulates the transcription of genes showing specific response elements (REs) on their promoter regions to which it binds through their DNA binding domain (DBD), once it is activated by known ligands [71]. In contrast to the DBD, its ligand binding domain (LBD) exhibited an evolutionary low degree of conservation [71] and thus, PXR ligands might differ across species [71,72]. PXR signaling cascade regulations seem to be further puzzling, as PXR subcellular localization and transcriptional activity are also dependent on multiple post-translational modifications, including phosphorylation, acetylation, SUMOylation, and ubiquitination [73]. Our understanding on how PXR function in vertebrate species other than mammalian species is still limited. Several studies have suggested as VK and warfarin might bind to mammalian's PXR as ligands, using a diverse set of methodological approaches $[17,71,74]$. However, only in vivo and in vitro transcriptional approaches suggest, as fish PXR transcriptional activation through these compounds might be evolutionary retained from teleosts $[20,37]$.

In mammals, PXR is mainly expressed in liver and intestine, where the PXR-mediated gene activation program is primarily recognized to increase drug metabolism, drug transport, and drug efflux pathways in these tissues. However, the control of retinoid metabolism, inflammation, iron, glucose, lipid, cholesterol, bile acid, and bilirubin homeostasis, as well as the regulation of bone mineral density, were also demonstrated $[19,70,75,76]$. In this sense, mammalian pxr transcripts have also been detected in osteoblastic and neural cells, as well as in the endothelial cells of the blood-brain barrier (BBB) [17-19,77]. In fish, a broad distribution of pxr expression in tissues/organs was reported in different species $[20,37,78,79]$. Fish $p x r$ transcripts were specifically detected at brain (granular layer), eyes (inner nuclear and nerve fiber layers as well as rod nucleus), cartilage (cell rich hyaline cartilage), bone, intestine, liver, gonads, spleen, and kidney [20,80], widening the potential implication of PXR signaling in the development and physiological status of vertebrates, including its reproductive performance.

\section{The Impact of Vitamin $\mathrm{K}$ in Reproduction}

Reproduction is a tightly regulated biological process that guarantees species perpetuation and increases intra-specific genetic variability, allowing for offspring to increase its fitness and adaptation to the environmental changes and avoiding the extinction. Although vertebrates exhibit a diverse set of modes of sexual reproduction (including hermaphroditism), with oviparous, ovoviviparous, 
or viviparous offspring production, semelparity or iteroparity (with single (seasonal), or multiple reproductive cycles along the year), as well as with synchronous, group-synchronous, and asynchronous gonadal development; it requires a myriad of precisely orchestrated events, governed by host signaling pathways that are considerably conserved along its evolution [81]. A great research effort has been paid to understand the physiological changes and the related underpinning molecular pathways in order to warrant successful reproduction and solve reproductive disorders. Consequently, it is known that reproductive fitness may be influenced by life conditions, as obesity, stress, environmental pollution, and/or daily dietary intake of particular nutrients [82-85]. Although reproductive system development and regulation is a continuous process, in the present article we will review (i) the gonad development, (ii) the hypothalamus-pituitary-gonad (HPG) axis regulation, and (iii) the tissue crosstalk with relevant organs and signaling pathways separately, in order to simplify the highly complex picture. Along the description of such processes, the different pieces of evidence showing the puzzling impact of VK on vertebrate's reproduction will be highlighted, supporting the role of VK in this process, in addition to the known association between protein Z (a VKDP with extrahepatic $\gamma$-carboxylation) and pregnancy outcome in humans (reviewed in [86]).

\subsection{Direct Impact of Vitamin K on the Gonads}

Gonad development and maturation is a process that is controlled through different signaling pathways at the local level (Figure 3). In males, spermatogenesis can be generally divided in three different phases: mitotic, meiotic, and spermiogenic. During the mitotic phase, the undifferentiated spermatogonia A, through the action of a well-defined and diverse set of growth factors and molecules (including stem cell factor (SCF), glial cell-derived neurotrophic factor (GDNF), bone morphogenetic protein 4 (BMP4), fibroblast growth factor 2 (FGF2), insulin like growth factor 1 and 2 (IGF-1 and 2), insulin (Ins), retinoic acid (RA), and triiodothyronine $\left(\mathrm{T}_{3}\right)$ ), differentiates and leads to the formation of the spermatogonia $B$, which is characterized by a more rapid mitotic division potential [87-90]. At the meiotic phase, primary and secondary spermatocytes differentiate and proliferate under the control of follicle-stimulated hormone (FSH). In order to directly induce spermatocytes meiosis, in Sertoli cells, FSH binding to its receptor leads to the activation of the gene expression of neuregulin 1 and 3 ( $n$ rg 1 and 3, respectively). Similar to FSH, retinoic acid (RA) also has the capacity to induce the transcription of both $n r g 1$ and 3, through the binding to its own receptors, as demonstrated in Nrg1 ${ }^{\text {Ser- } /-}$ mutant mice (reviewed in [89]). In addition, FSH up-regulates nociceptin (N/OFQ), which promotes the phosphorylation of the meiotic recombination protein REC8 homolog (REC8), triggering chromosome dynamics during spermatocyte meiosis (reviewed in [89]). Testosterone, through canonical and non-canonical signaling pathways, regulates different and key biological processes that are required for proper spermatid maturation, such as oxidative metabolism, DNA repair, RNA processing, apoptosis, and/or meiotic division, as demonstrated in murine models under testosterone suppression (reviewed in [91]). In particular, testosterone is needed in order to initiate the transcription of occluding and claudins 3 and 11, in order to warrant blood-testis barrier (BTB) maintenance, as well as the one of cadherins, integrins, and laminins to form protein complexes to attach Sertoli cells to elongated spermatids. 


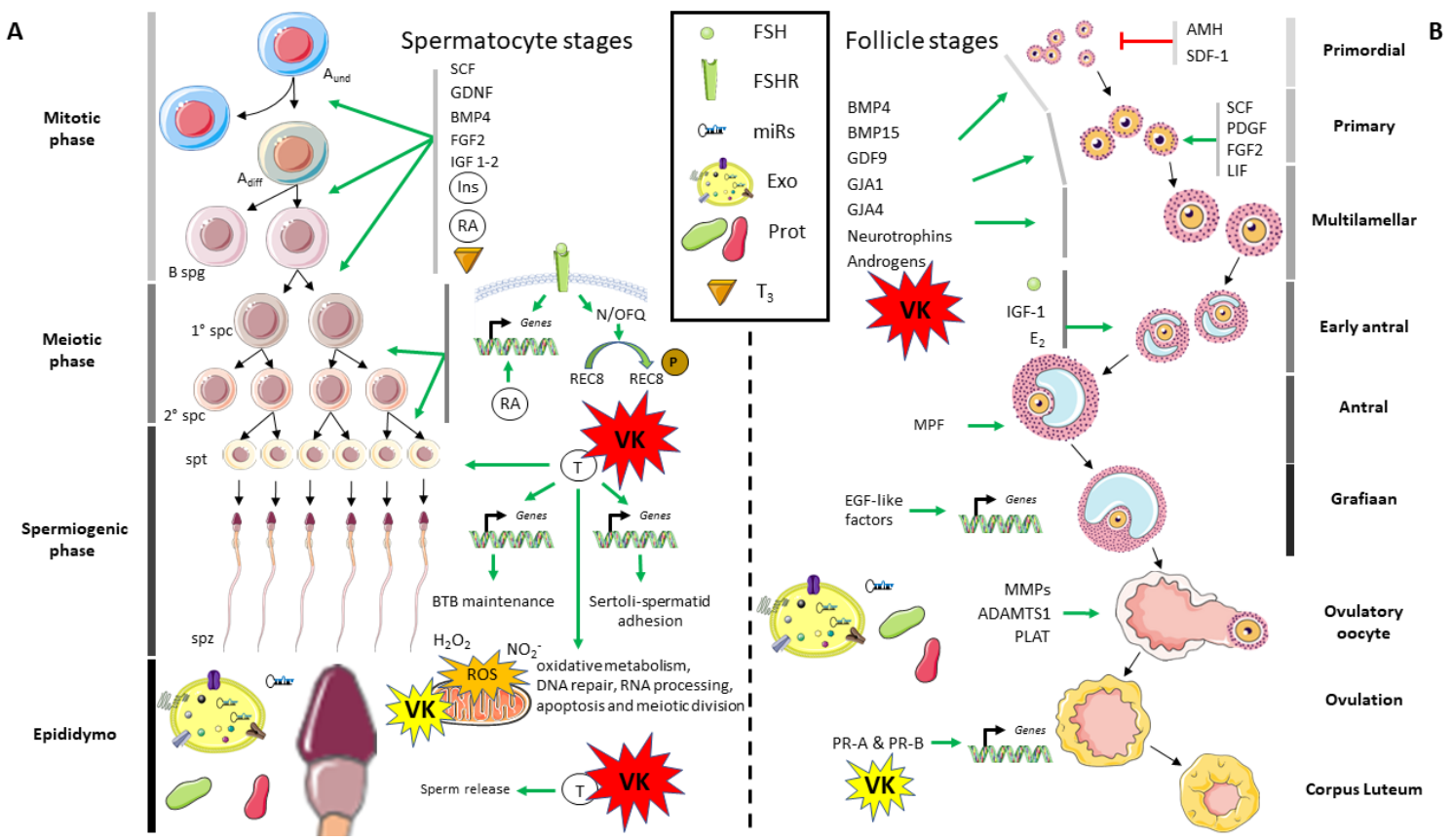

Figure 3. Gonad development and related molecular pathways in vertebrates. General overview of spermatogenesis (A) and oogenesis (B), specifying some of the most relevant pathways. The particular mechanisms by which vitamin $\mathrm{K}(\mathrm{VK})$ has a demonstrated effect on gonad development are highlighted in red, while those showing potential evidences are highlighted in yellow. ADAMTS1, a disintegrin-like and metallopeptidase with thrombospondin type 1 motif, $1 ; A_{\text {diff, differentiated spermatogonia A; }}$ $A M H$, anti-Müllerian hormone; $A_{\text {und }}$, undifferentiated spermatogonia $\mathrm{A} ; B s p g$, spermatogonia $\mathrm{B} ; B M P 4$, bone morphogenetic protein 4 ; $B M P 15$, bone morphogenetic protein $15 ; B T B$, blood-testis barrier; $E_{2}$, estradiol; EGF-like factors, epidermal growth factor-like factors; FGF2, fibroblast growth factor 2; FSH, follicle-stimulating hormone; FSHR, follicle-stimulating hormone receptor; GDF9, growth differentiation factor 9; GDNF, glial cell-derived neurotrophic factor; GJA1, gap junction alpha-1 protein; GJA4, gap junction alpha-4 protein; IGF 1-2, insulin like growth factor 1 and 2; Ins, insulin; LIF, leukemia inhibitory factor; $M M P$, matrix metalloproteinases; $M P F$, maturation-promoting factor; $N / O F Q$, nociceptin/orphanin FQ; $P$ in brown circle, phosphorylated protein; $P D G F$, platelet-derived growth factor; $P L A T$, tissue-type plasminogen activator; $P R-A$, progesterone receptor $\mathrm{A} ; P R-B$, progesterone receptor $\mathrm{B}$; $R A$, retinoic acid; REC8, meiotic recombination protein REC8 homolog; SDF-1/CXCL12, stromal cell-derived factor- 1 ; $S C F$, stem cell factor; $s p t$, spermatid; $s p z$, spermatozoa; $1^{\circ} s p c$, primary spermatocyte; $2^{\circ} s p c$, secondary spermatocyte; $T$, testosterone; $T_{3}$, triiodothyronine.

Nowadays, it is clear that both main molecular pathways of VK, PXR transcriptional activation, and $\gamma$-carboxylation, are present in main tissues involved in vertebrate's reproduction, the brain and the gonads. Transcripts of $p x r, g g c x$, and vkors were specifically found in the pituitary, testis, and ovaries in different vertebrate species, from fish to mammals [18,20,22,31,37,56,78,80,92,93]. Although, in mammals, PXR can be transactivated by molecules other than VK and VK anticoagulants, like warfarin, as well as its specific ligands may differ from fish to mammalian species [71,94], transcriptional activation of cyp3a1 through PXR by VK might be a key step on the control of progesterone, cholesterol, and testosterone synthesis [95] and thus, of the reproductive system, as demonstrated by in silico and in vitro assays using primary rat hepatocytes. Pxr-deficient rodents shows poor breeding success [96]. Furthermore, the activation of PXR in humans and rodents leads to the transcription of genes encoding phase I enzymes, including cyp3a4, cyp3a23, cyp3a11, cyp $2 b 6$, cyp $2 b 9$, cyp $2 c 55$, cyp $2 c 8$, cyp $2 c 9$, cyp2c19 and cyp1a, but also phase II enzymes (eg. UDP-glucuronosyl transferase (ugt), sulfotransferase (sult), and glutathione S-transferase (GST) enzymes), both controlling the synthesis and metabolism of steroids such estrogen $\left(\mathrm{E}_{2}\right)$, among other compounds (reviewed in [97]); being particularly important 
CYP3A4 and SULT2A1, known to act on the metabolic deactivation of androgens [98]. In this sense, the transactivation of PXR in porcine Leydig cells increased the expression of cytochrome B5A and cytochrome B5 reductase 1, as well as hydroxysteroid (17-beta) dehydrogenase 4 and retinol dehydrogenase 12 genes that are involved in steroidogenesis [99]. The undoubtedly demonstration of VK playing a key role on reproduction might come from nutritional studies. Rats fed with VK deficient diets had low expression of cyp11a - a rate-limiting enzyme in testosterone synthesis-where mRNA levels were positively correlated with the MK-4 concentration in testis [54]. The effect of VK on testosterone levels (at testis and/or plasma) seemed to be evolutionary conserved between fish and mammals, as increasing the dietary VK levels increased the testosterone levels in both mammalian $[54,55]$ and fish species [49]. The impact of VK on spermatogenesis through the exposure to warfarin (a VK recycling inhibitor) was further described recently. Sprague-Dawley rats fed with a diet containing warfarin had a delayed spermiation, presence of multinucleated giant cells in the seminiferous tubules, germ cells degeneration, asthenozoospermia, oligozoospermia, increased percentage of abnormal sperm morphology, and lower sperm concentration and motility when compared to the controls [100]. These results on the rat testis were correlated not only with the lower serum testosterone level, but also with a higher serum LH level [100].

It seems like VK has still conserved its role as an important antioxidant molecule from invertebrates. Because spermatozoa have limited antioxidant defense mechanisms and a limited capacity for detection and repair of DNA damage, these cells are among the most vulnerable to oxidative stress. Indeed, oxidative stress has been linked to male infertility, inducing reduced sperm motility, sperm DNA damage, and increased risk of recurrent abortions and genetic diseases, although certain levels of reactive oxygen species (ROS) are required for the maturation of spermatozoa, acrosome reaction, capacitation, hyperactivation, and spermatocyte fusion in humans (reviewed in [101]). Although oxidative status was not specifically determined in Senegalese sole (Solea senegalensis) broodstock fed control and dietary VK1 supplemented diets during six months, Fernández and colleagues [49] found lower sperm DNA fragmentation in Senegalese sole males fed supplemented diet, in line with an improved antioxidant capacity of juvenile Jian carp (Cyprinus carpio var. Jian) fed increased levels of dietary VK [102], and the in vitro elimination of intracellular ROS through VKORC1L1 in the presence of VK [46]. As previously mentioned, vkorc1l1 was found to be expressed in the testis of vertebrates, including rodents [60] and Senegalese sole [31]. Furthermore, VKORC1L1 KO cells are sensitive to oxidative stress, while VK1 supplementation seemed to compensate their cell stress [103]. Thus, VK1 and/or VK2 dietary supplementation might be another antioxidant therapy to prevent male infertility through ROS, as has been already demonstrated for vitamin C, vitamin E, selenium, zinc, and glutathione in humans (reviewed in [101]).

In mammals, spermatozoa will mature at epididymis through the interaction with different molecules, proteins, and microRNAs (miRs) (included in exosomes or not), and finally induced to be released by testosterone $[91,104,105]$. In addition to the regulation of testosterone synthesis by VK (above-mentioned), VK might also affect spermatogenesis through the post-transcriptional regulation of miRs (please, see the specific section of tissue crosstalk in this sense).

In females, the gametogenesis process is also quite conserved along evolution, and the detailed review performed by [106] in mammalian gametogenesis is highly recommended for a deeper lecture. In mammals, the first steps of folliculogenesis (from primordial to multilamellar follicles) are known to be gonadotropins-independent phases. Anti-Müllerian hormone (AMH) and stromal cell-derived factor-1 (SDF-1/CXCL12) inhibit primordial follicle recruitment (reviewed in [107]). In contrast, while stem cell factor (SCF), platelet-derived growth factor (PDGF), fibroblast growth factor 2 (FGF2), and leukemia inhibitory factor (LIF) specifically promote the transition from primordial to primary follicles [106], different growth factors, including bone morphogenetic protein 4 (BMP4) and 15 (BMP15), growth differentiation factor 9 (GDF9), gap junction alpha-1 protein (GJA1, also known as Connexin 43), gap junction alpha-4 protein (GJA4, also known as Connexin 37), neurotrophins and/or androgens, stimulate oocyte growth, granulosa, and theca cells proliferation. The effect of VK on 
male gametogenesis might also occur in female gametogenesis, where a dietary VK supplementation also increased the plasma testosterone levels in Senegalese sole females [49]. If VK also regulates the synthesis of steroids in ovaries through PXR, VK nutritional status might also affect multilamellar and early antral follicles recruitment and ovulation. Furthermore, the detected expression of vkorc1 and vkorc1l1 as well as $g g c x$ in male and female gonads suggest that VK is required and recycled for vertebrate's reproduction $[31,56,92]$. Nevertheless, it still remains to uncover whether i) the local $\gamma$-carboxylation of VKDPs and/or VK antioxidant function is the required pathway for assuring reproductive success or ii) if the transactivation of PXR through VK is the main driver pathway of VK effects on gametogenesis.

During the mammalian early antral and antral follicle maturation with a continuous granulosa cells proliferation, insulin like growth factor 1 (IGF-1), and $E_{2}$, in addition to FSH, play an important role. Only the most mature antral follicles (most sensitive to FSH action) go on towards its maturation until the dominant follicle recruitment. LH surge-induced factors are essential for the oocyte meiotic resumption, cumulus expansion, until the ovulation, and luteinization in mammals. In this sense, maturation-promoting factor (MPF) leads to oocyte meiotic resumption, while epidermal growth factor-like factors (EGF-like factors) activate the expression of prostaglandin synthase 2 (ptgs2), hyaluronan synthase 2 (has2), and tumor necrosis factor (TNF) $\alpha$-induced protein 6 (tnfaip6) in order to the cumulus expansion to take place. For follicle rupture in mammals, the action of matrix metalloproteinases (MMPs), tissue-type plasminogen activator (PLAT), and a disintegrin-like and metallopeptidase with thrombospondin type 1 motif (ADAMTS1) is required [106]. In the meanwhile, mammalian oocytes interact with different proteins, metabolites, and miRs packaged in exosomes that are present in the follicular fluid's [105,108], being finally ovulated upon the transcriptional activation of endothelin 2 (edn2), cGMP-dependent protein kinase 2 (prkg2), interleukin 6 (il6), and synaptosome associated protein 25 (snap25) genes through the action of progesterone receptors (PR-A and PR-B; reviewed in [106]). Because PXR control the steroid synthesis and metabolism, including progesterone, this might represent another mechanism by which VK might influence progesterone receptors transactivation and thus, ovulation, which remains to be elucidated.

Oxidative stress may also affect ovaries, being ROS involved in the initiation of apoptosis in antral follicles caused, for instance by several chemical and physical agents in mammalian species (reviewed in [109]). Antral rat follicles suffered apoptotic death without gonadotropin support, while the capacity of FSH to suppress it was strongly associated to follicular glutathione (GSH) synthesis. In cultured rat ovarian follicles, the antioxidants superoxide dismutase (SOD), catalase, $N$-acetyl cysteine and ascorbic acid, are all able to inhibit apoptosis in antral follicles in the absence of FSH [110]. Thus, VK might also protect primordial and primary follicles from death if its antioxidant role in vertebrates is confirmed. In this sense, an increased oxidative stress response (at transcriptional level) in zebrafish (Danio rerio) embryos under VK-induced deficiency was found [41]. Nevertheless, the potential preventive antioxidant role of VK1 and VK2 is not observed for its analog, the menadione (VK3). It is known that while in vivo treatment of neonatal mice with increasing menadione doses decreased the total number of follicles per section, in vitro cultured ovaries exposed to menadione showed oxidative DNA lesions and activated caspases, probably through lipid peroxidation [6].

In addition to the potential effects of VK on testosterone synthesis and the antioxidant status, VK might also affect gametogenesis through other particular pathways, such as some of the VKDPs and its carboxylation status. In this sense, protein S (PROS1) and GAS6 are also expressed in the testis of Sprague-Dawley rats [100], and both PROS1 and GAS6 act as specific ligands for the TAM (TYRO, AXL and MERTK) family of receptor protein tyrosine kinases that play an important role on reproductive system (reviewed in [111]), among other tissues such as brain (see below). Because VK deficiency might impair the action of those VKDPs through its carboxylation status, the altered intracellular $\mathrm{Ca}^{2+}$ homeostasis in particular tissues (such as testis) due to the limited carboxylation of these VKDPs, might be an additional relevant pathway on reproduction. 


\subsection{The Vitamin K Impact on the Hypothalamus-Pituitary-Gonad Axis}

In vertebrates, the HPG axis control gametogenesis and reproduction performance in a tightly regulated manner (Figure 4). In females, at the top of the axis, anteroventral periventricular and arcuate nucleus-derived kisspeptin (KISS) induces the release of gonadotropin-releasing hormone (GnRH) at the hypothalamus [112], which, in turn, stimulates gonadotropic cells to synthetize and secrete luteinizing hormone (LH) and follicle-stimulating hormone (FSH) in the anterior pituitary [113]. Recent studies in zebrafish also showed as GnRH isoforms are also produced in the testis, and may contribute to the control of testicular germinal cell development and function [114]. Through the release and transport by circulatory system, LH and FSH can reach the target tissue: the gonads. Majorly, LH regulates the steroidogenesis in the Leydig [115] and Theca [106] cells, whereas FSH supports gametogenesis in Sertoli $[89,116]$ and Granulosa cells [106]. In different mammalian species, upon LH stimulation, there is a feedback negative regulation in the HPG axis through testosterone release from testis, inhibiting pituitary LH production $[117,118]$. In contrast, LH-stimulated testosterone release from ovaries inhibits KISS production [119]. Similarly, LH-stimulated progesterone release from ovaries inhibits LH surge and pulsatile secretion that occurs at the pre-ovulatory stage through KISS upstream signaling, via progesterone receptor in the arcuate (ARC) and/or anteroventral periventricular (AVPV) nuclei in Sprague-Dawley rats [120]. FSH induces estradiol release from both testis and ovaries. While estradiol from mammalian testis represents another negative feedback mechanism on the HPG axis, at the level of GnRH and LH production [118], estradiol from ovaries can both inhibit (at the ARC) or stimulates KISS production (at the AVPV), as demonstrated in murine models [121]. Upon FSH stimulation, secreted inhibins from both mammalian testis and ovaries may also represent another major negative feedback mechanism on the HPG axis acting at the pituitary FSH production [106,117]. When considering the reported in vivo VK induction of testosterone synthesis and release from rodents and fish gonads to blood stream (above-mentioned) $[49,54,55,100]$, it is a key point on the HPG axis to count on.

Hypothalamic neurons synthesizing KISS play a key role in the central regulation of the timing of puberty onset and reproduction in mice [122]. Saedi and co-authors [112] reviewed the tight control of the KISS signaling through neurotransmitters and neuropeptides at the human and rodent hypothalamus. Leptin, synthesized in adipocytes, is a permissive factor for puberty onset and that signaling is increased by androgens in female rats [123]. Leptin acts on KISS-positive neurons indirectly, through the cocaine- and amphetamine-regulated transcript (CART), a potent stimulator of neurons expressing KISS and GnRH, as demonstrated by the high fat diet-induction of early puberty in mice [124]. At the same time, leptin inhibits the activity of agouti-related peptide (AgRP)-expressing neurons [125], which are other cell regulators of female fertility in mouse [126]. AgRP-expressing neurons also express $\gamma$-aminobutyric acid (GABA) and neuropeptide $Y$ (NPY), and they are tightly connected to both ARC and AVPV nuclei. Indeed, the ablation of these neurons in mice lacking leptin restored mice fertility [126]. NPY is also known to stimulate KISS signaling [127] as well as other neuropeptides, such as tachykinin-3 (TAC3, cleaved into neurokinin-B (NKB) chain) [128], as demonstrated by in vitro and in vivo assays with mouse model. Additional signals may also be involved, including the glutamate. Glutamate is the principal excitatory neurotransmitter of the central nervous system (CNS) and a known co-factor to facilitate KISS signaling [129]. In contrast, different studies in mammals have proved that high prolactin (PRL) levels and dynorphin inhibit the KISS signaling pathway $[130,131]$. Once secreted, KISS binds its G-protein coupled receptor on GnRH-positive neurons to stimulate GnRH synthesis in mammalian species (in [121]). It is not yet clear the role of GABA and glutamate transmissions on the KISS/GnRH signaling regulation, and it might differ in various physiological stages, as demonstrated in mice and ewe models [132,133]. GnRH neurons are surrounded by many populations of GABAergic and glutamatergic neurons, which neural transmission impact on the KISS/GnRH signaling. Indeed, estradiol induced changes in GABAergic and glutamatergic transmission may be involved in multiple aspects of negative and positive feedback on the GnRH neuronal activity in mice [132,134]. Nevertheless, exposure to agonist 
and antagonists of GABA receptors suggested that GABA is an important mechanism that may be involved in the biosynthesis of GnRH and GnRH receptor as well as in the GnRH release in mice and female ewes $[133,135]$.

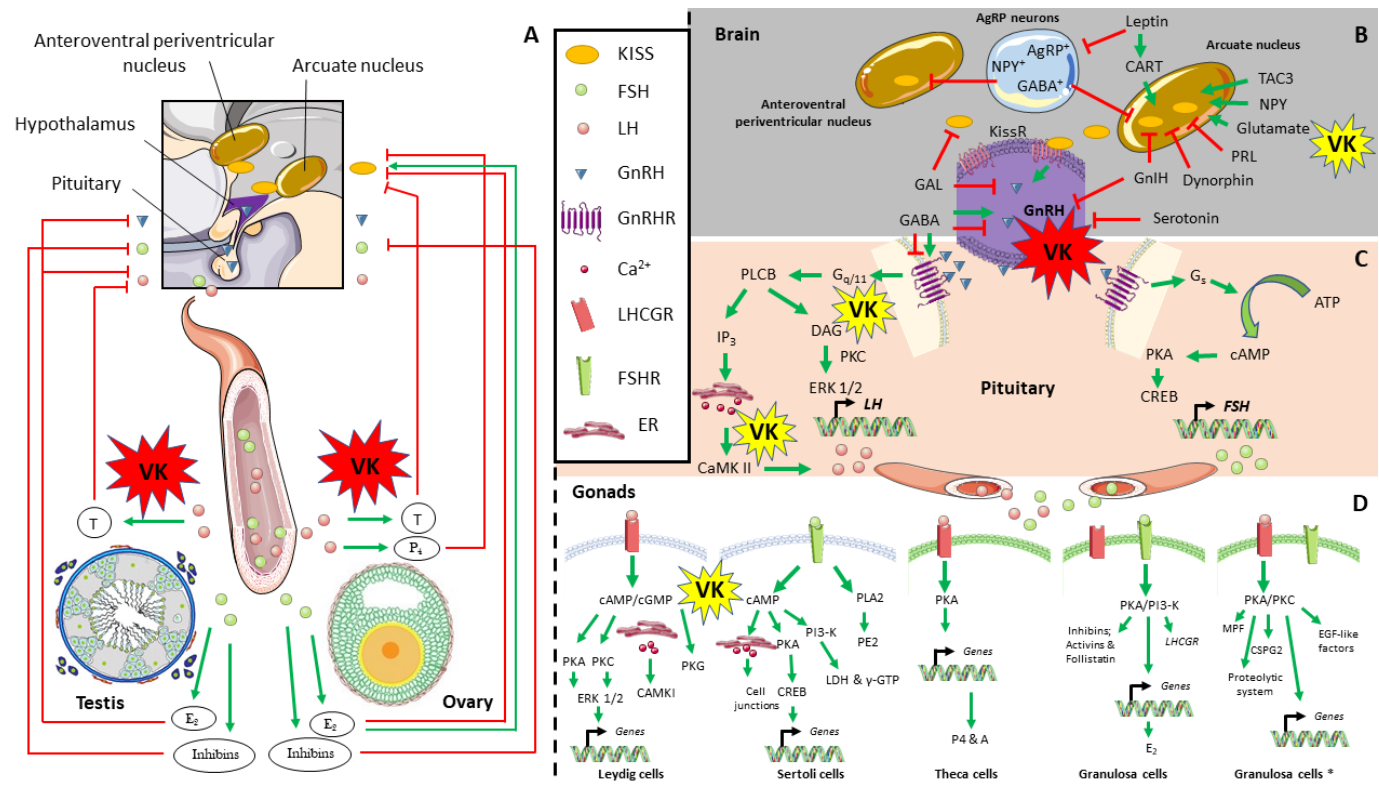

Figure 4. Hypothalamus-pituitary-gonad (HPG) axis in vertebrates and related molecular pathways. General hormonal control of the HPG axis, from neural kisspeptin stimulation to gonadal testosterone and androgens feedback regulation (A). Hormonal control of GnRH synthesis and release at brain (B). GnRH signaling pathway for FSH and LH synthesis (C). FHS and LH signaling pathway at specific cells from testis and ovaries: Leydig, Sertoli, Theca, Granulosa cells (D). The particular mechanisms by which vitamin K (VK) has a demonstrated effect on HPG axis are highlighted in red, while those showing potential evidences are highlighted in yellow. The asterisk indicates Granulosa at pre-ovulation stage, whereas green arrows and red lines indicate stimulatory and inhibitory activity, respectively. The symbol + indicates cells expressing particular genes. $A$, androstenedione; $A g R P$, agouti-related peptide; $A T P$, adenosine triphosphate; CAMK I, calcium/calmodulin kinase I; CAMK II, calcium/calmodulin-dependent kinase II; $C A M P$, cyclic adenosine monophosphate; $C A R T$, cocaine- and amphetamine-regulated transcript; $c G M P$, cyclic guanosine monophosphate; $C R E B$, cAMP response element (CRE) binding protein; CSPG2, chondroitin sulfate proteoglycan 2; DAG, diacylglycerol; $E_{2}$, estradiol; EGF-like factors, epidermal growth factor-like factors; ERK 1/2, mitogen-activated protein kinase; $F S H$, follicle-stimulating hormone; $F S H R$, follicle-stimulating hormone receptor; $G A B A$, gamma-aminobutyric acid; GAL, galanin; $\Gamma$-GTP, $\gamma$-glutamyl transpeptidase; $G n I H$, gonadotropin inhibitory hormone; $G n R H$, gonadotropin releasing hormone; $G n R H R$, gonadotropin releasing hormone receptor; GPRC6A, G protein-coupled receptor class $C$ group 6 member; IP3, inositol trisphosphate; KISS, kisspeptin; KISSR, kisspeptin receptor; $L D H$, lactate dehydrogenase; $L H$, luteinizing hormone; LHCGR, luteinizing hormone/choriogonadotropin receptor; $M P F$, maturation-promoting factor; NPY, neuropeptide $Y$; $P 4$, progesterone; $P I 3-K$, phosphatidylinositol 3-kinase; $P K A$, protein kinase A; $P K C$, protein kinase C; $P K G$, protein kinase G; $P L A 2$, phospholipase A2; $P L C B$, phospholipase $C \beta$; ER, endoplasmic reticulum; $T$, testosterone; $T A C 3$, tachykinin-3.

The impact of VK on neuronal development and homeostasis should not be also neglected when considering the tight control of brain over reproductive system through the HPG axis. GAS6 also has a central role in the development and survival of nervous system. As previously commented, GAS6 activates the TAM family of receptor tyrosine kinases, particularly involved in the proliferation and survival of GnRH neurons, allowing their migration from the olfactory bulb to the hypothalamus, as demonstrated by in vitro assays (reviewed in [51]). Furthermore, different transcripts of $p x r$ were also 
specifically found to be expressed in the brain and pituitary in both genders from different vertebrate species $[18,20,37,78,93]$. Through in situ hybridization (ISH), we found a particular $p x r$ transcript (sspxr1) in Senegalese sole to be expressed in the granular layer [20], a densely packed layer containing mossy fibers, the cell bodies of granule cells, uni-polar brush cells, and Golgi cells. This layer releases the neurotransmitter glutamate [136] and it represents a complex communication network between its own cells and those from other brain (outer) layers (Purkinje and molecular layers). Therefore, this might represent another hypothetical pathway by which VK might influence the cellular responses that are involved in the HPG axis control of the reproductive system.

On another hand, GnRH signaling is repressed by gonadotropin inhibitory hormone $(\mathrm{GnIH})$ in rat and sheep females (in [121]). Recently, GnIH have been also found to regulate testicular development and function through changes in steroidogenesis and controlling GnRH-induced response in vitro [137]. GnRH signaling in female mice is also repressed by galanin (GAL), which inhibits the activity of GnRH (in [112]), while serotonin inhibits gnrh expression in female mice [138]. Because any neurobiological alteration on these players changes the GnRH neuronal activity needed to generate the GnRH surge and ultimately trigger ovulation, different environmental or intrinsic clues might indirectly affect HPG axis and reproductive performance. Pulsatile secretion of GnRH towards the gonadotropic cells at the anterior pituitary stimulates LH and FSH synthesis. GnRH exerts its action through its receptor (GnRHR), a seven-transmembrane receptor that is associated with two different $G$ proteins, $G_{q / 11}$ and $G_{s}$ (demonstrated in primary pituitary cell culture, in vivo murine models, and immortalized cell culture, reviewed by [113]). High $\mathrm{GnRH}$ pulse frequency preferentially activate the $\mathrm{G}_{\mathrm{q} / 11}$ protein stimulating phosphatidylinositol-specific phospholipase $C$ beta (PLC $\beta$ ), which in turn induced inositol trisphosphate $\left(\mathrm{IP}_{3}\right)$ and diacylglycerol (DAG) synthesis. The former stimulates $\mathrm{Ca}^{2+}$ release from the smooth ER, whereas the latter leads to protein kinase C (PKC) activation. $\mathrm{Ca}^{2+}$ and PKC-mediated the activation of calcium/calmodulin-dependent kinase II (CAMK II) and (mitogen-activated protein kinase) ERK 1/2, respectively, finally inducing th gene expression. Conversely, when GnRH is pulsed with low frequency, cyclic adenosine monophosphate (cAMP) production occurs through $\mathrm{G}_{\mathrm{s}}$ protein recruitment. cAMP increased intracellular levels, activate protein kinase A (PKA), and consequently cAMP response element binding protein (CREB) phosphorylation that enhance the $f$ sh gene expression.

These intracellular communications and signaling pathways might be also altered by VK. VK also induced sphingolipid synthesis, a major class of lipids and a vital modulator of neural cell proliferation, differentiation and survival in mammals (reviewed in [51]). We have recently reported how VK dietary supplementation in male Senegalese sole induced a differential expression of some particular ncRNAs in blood plasma. A bioinformatic prediction of the targets of these ncRNAs identified several genes that were specifically involved in sphingolipid (lpin3) and glycerophospholipid (cept1b and lpin3) metabolism and/or signaling, in addition to calcium/calmodulin dependent protein kinase II beta (camk2b1) gene [49]. While lipins (Lpin1, 2, and 3) are known to regulate fatty acid metabolism, particularly the conversion of phosphatidic acid to DAG; Cept1 catalyzes the de novo synthesis of phosphatidylcholine (PC) and phosphatidylethanolamine (PE) from DAG, critical for homeostasis of cellular lipid stores and membranes, but also to induce the expression of LH in the pituitary, as demonstrated by in vitro studies $[113,139,140]$. Indeed, the release of $\mathrm{Ca}^{2+}$ from the ER controls the activation of calcium/calmodulin kinase I (CAMKI) and II (CAMKII), as well as cell junctions at pituitary, Leydig and Sertoli cells might be an additional pathway where VK may act through these ncRNAs targeting camk2b1.

In mammalian testis, LH binding to luteinizing hormone/choriogonadotropin receptor (LHCGR) induces cAMP and cyclic guanosine monophosphate (cGMP) increase in Leydig cells. Consequently, PKA, PKC, and protein kinase G (PKG) activity is stimulated, as well as $\mathrm{Ca}^{2+}$ released from ER. While $\mathrm{Ca}^{2+}$ release activates CAMKI, PKA and PKC induce the expression of several steroidogenic genes through ERK 1/2 signaling pathway, in particular: steroidogenic acute regulatory protein (STAR), cholesterol side-chain cleavage enzyme (also known as cytochrome P450 11a1; CYP11A1), steroid 17-alpha-hydroxylase/17,20 lyase (also known as cytochrome P450 17a1; CYP17A1), 3 beta-hydroxysteroid 
dehydrogenase/Delta 5->4-isomerase type 1 (HSD3B1), and/or testosterone 17-beta-dehydrogenase 3 (also known as 17-beta-hydroxysteroid dehydrogenase type 3; HSD17B3) [115]. In Sertoli cells from mammals, FSH induces $\mathrm{Ca}^{2+}$ release at ER and stimulates PKA and phosphatidylinositol 3-kinase (PI3-K) through cAMP. While $\mathrm{Ca}^{2+}$ release from ER regulates Sertoli-Sertoli cells junction communication, PKA activation stimulates the expression of aromatase (also known as cytochrome P450 19A1; CYP19A1), tissue-type plasminogen activator (PLAT), insulin like growth factor 1 (IGF-1), and stem cell factor (SCF) genes that potentiates spermatogonia survival. Furthermore, PI3-K stimulates $\gamma$-glutamyl transpeptidase $(\gamma-g t p)$ and lactate dehydrogenase (ldh) expression, the latter being involved in the lactate production for germ cells development. In addition, FSH also activates phospholipase A2 (PLA2) pathway, leading to prostaglandin E2 (PE2) release [116]. In the mammalian ovary, at the antral follicles, LH preferentially target Theca cells to stimulate steroidogenesis, increasing the gene expression of star, cyp11a1, hsd3b1, hsd3b2, and cyp17a1 through PKA signaling and producing androgens and progesterone (P4). Instead, in the Granulosa cells of antral follicles, FSH binds to its receptor, activates PKA and PI3-K signaling, inducing activins, inhibins, and follistatin, as well as supporting androgen aromatization to estrogens, oocyte growth, and granulosa cells proliferation through increasing the expression of cyclins, cyclin-dependent kinases, aromatase, and cyp17a1. In parallel, the expression of $l$ hcgr is also induced [141]. At the pre-ovulatory stage, LH surge acts in the Granulosa cells to regulate the final steps of folliculogenesis $[106,142]$. In this sense, PKA and PKC signaling pathways are activated in order to induce maturation-promoting factor (MPF), chondroitin sulfate proteoglycan 2 (CSPG2), proteolytic system, and epidermal growth factor-like factors (EGF-like factors), as well as the expression of progesterone receptors ( $p r-a$ and $p r-b$ ).

\subsection{The Vitamin K Impact on Tissue Crosstalk Relevant for Reproductive Performance}

The crosstalk of some peripheral organs/tissues with the reproductive system is important to regulate steroidogenesis and gametogenesis. Figure 5 depicts the main tissue crosstalk points that are relevant for reproduction success. In vertebrates, the thyroid gland exerts a key crosstalk regulation of reproduction through the synthesis and release of thyroid hormones (THs), triiodothyronine $\left(\mathrm{T}_{3}\right)$, and thyroxine (T4; reviewed in [143]). THs concentration is critical for brain development during the embryonic development and neonatal life, but also in energy metabolism, lipid synthesis and degradation, linear growth, bone maturation, and remodeling (as reviewed in [143]). Besides, there is a clear crosstalk between HPG axis and THs. Thyrotropin-releasing hormone (TRH) is synthetized in the hypothalamus, which, in turn, regulates the thyroid-stimulating hormone (TSH) release from the anterior pituitary. The TSH target organ is the thyroid gland and/or follicles, where induces $\mathrm{T}_{4}$ synthesis and that can undergo deiodination to $\mathrm{T}_{3}$ through deiodinases (D1, D2, and D3; reviewed in [144]. How THs interact with the reproductive system may differ between vertebrate species, and particularly in fish species (reviewed in [90]). While TRH is involved in the activation of pituitary-thyroid axis in mammals, this seems to not occur in fish. Further, the pituitary secretion of TSH in fish seems to be dependent on corticotropin-releasing hormone ( $\mathrm{CRH})$, as observed in amphibians, reptiles, and birds. 


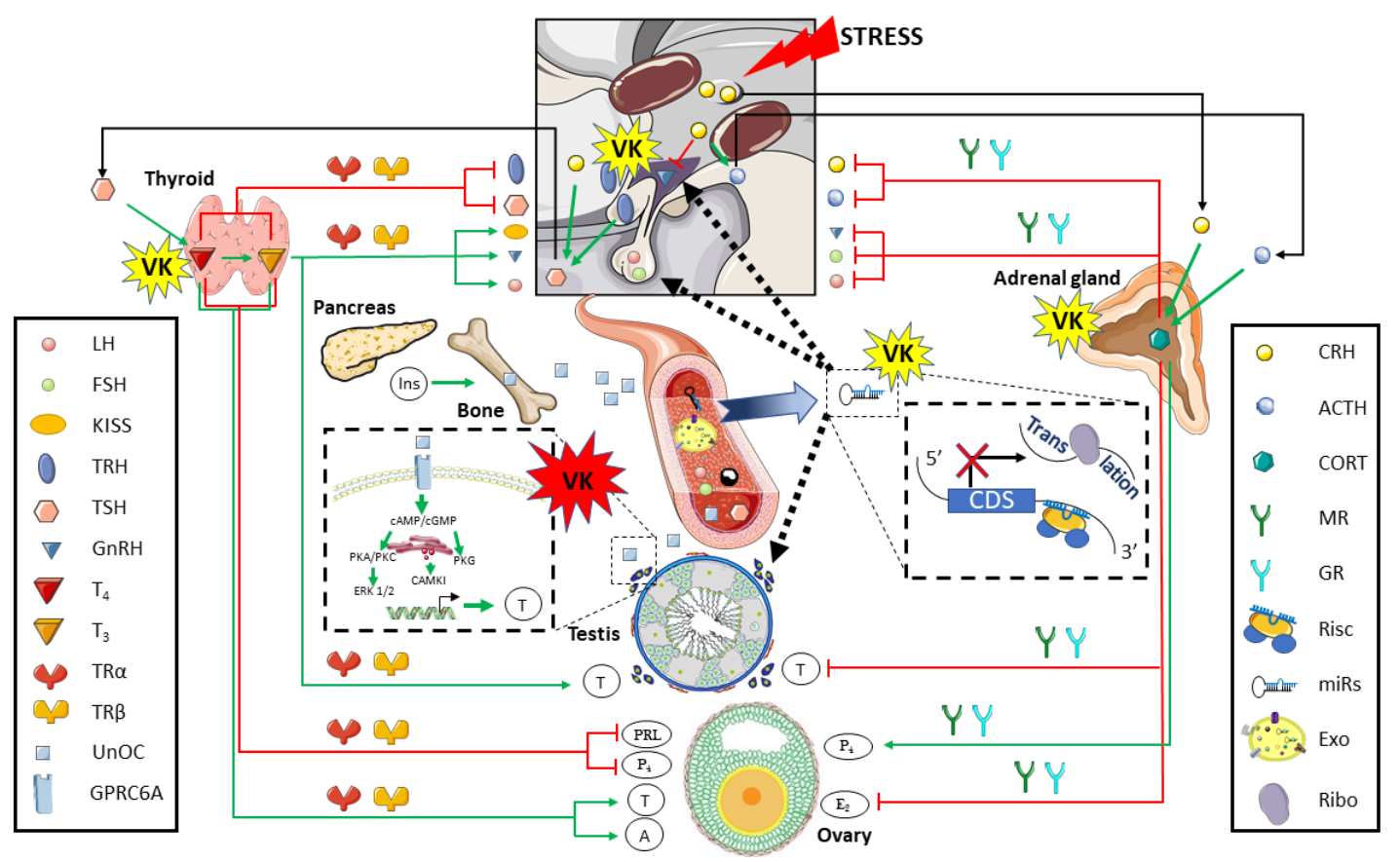

Figure 5. Tissue crosstalk in vertebrate gametogenesis and gamete quality. On the left hand, the crosstalk between the thyroid gland and the pancreas-bone with the hypothalamus-pituitary-thyroid (HPG) axis is depicted. On the right hand, the respective crosstalk between the stress response system and the adrenal gland with the HPG axis is presented, while the crosstalk of HGP and other tissues through the circulating non-coding RNAs (ncRNAs) whether included in exosomes or not is hypothesized. The particular mechanisms by which vitamin K (VK) has a demonstrated effect on reproductive tissue crosstalk are highlighted in red, while those showing potential evidences are highlighted in yellow. A, androgens; ACTH, adrenocorticotropic hormone; CDS, coding sequence; CORT, glucocorticoids; CRH, corticotropin releasing hormone; Exo, exosomes; E2, estradiol; D1, deiodinase type 1; D2, deiodinase type 2; D3, deiodinase type 3; FSH, follicle-stimulating hormone; $\mathrm{GnRH}$, gonadotropin-releasing hormone; GPRC6A, G Protein-Coupled Receptor Class C Group 6 Member; GR, glucocorticoid receptor; Ins, insulin; KISS, kisspeptin; LH, luteinizing hormone; miRs, microRNAs; MR, mineraloglucocorticoid receptor; PRL, prolactin; $\mathrm{P}_{4}$, progesterone; Ribo, ribosomal subunits; Risc, RNA-induced silencing complex; T, testosterone; TR $\alpha$, thyroid hormone receptor alpha; TR $\beta$, thyroid hormone receptor beta; TRH, thyrotropin-releasing hormone; TSH, thyroid-stimulating hormone; $\mathrm{T}_{4}, 3,5,3^{\prime}$, $5^{\prime}$-tetraiodothyronine; $\mathrm{T}_{3}, 3,5,3^{\prime}$-triiodothyronine; UnOc, uncarboxylated osteocalcin.

In mammals, once released to the blood stream, THs can be transported associated with globulin, transthyretin, and albumin [145] and thus, reaching target tissues and exerting their own known actions by binding to their NRs (thyroid hormone receptors; TRs). Elevated THs blood levels exert a negative feedback, inhibiting TRH and TSH release in a diverse set of vertebrates, including human, rat, bird and sheep, among other animals [146]. Silva and coauthors, in 2018 [147], reviewed thyroid hormones involvement in female reproduction in humans and other vertebrates, highlighting the thyroid hyperfunction association with androgens and testosterone synthesis, which then are metabolized to estrone and $E_{2}$, respectively, suggesting a positive THs control of aromatizable steroids in the ovary. In contrast, some studies evidenced a negative relationship between hypothyroidism and increased serum concentration of $\mathrm{P}_{4}$ and PRL, which cause a luteal phase prolongation, as demonstrated by hyperthyroidism induced premature luteolysis in rats (reviewed in [147]). In male tilapia (Oreochromis niloticus), $\mathrm{T}_{3}$ stimulates kiss and gnrh gene expression (reviewed in [147]), while hypothyroid conditions mediate a decrease of LH and testosterone levels in cockerel and rat (reviewed in [148]). In teleost fish, THs are associated with testicular development, growth, and maturation, through the promotion of 
germ cell proliferation and differentiation [90]. THs impact sexual differentiation and reproductive performance relies on the gene expression regulation of key steroidogenesis genes, such as androgen receptor (ar), steroid $5 \alpha$-reductase 1 (srd5alpha1) and 2 (srd5alpha2) aromatase (cyp19a1), as anti-Müllerian hormone (amh) and consequently estradiol levels in all vertebrates, as well as insulin-like growth factor binding protein 1 and 3 (igfbp $1 a$ and igfbp3), particularly in zebrafish [90].

Stress conditions are also important for reproductive success. Under stress, vertebrates increase the production of $\mathrm{CRH}$ at the hypothalamus that will stimulate the synthesis of the adrenocorticotropic hormone (ACTH) in the anterior pituitary. In humans, ACTH induces steroidogenesis [149], but also induce glucorticoids (CORT) synthesis in the adrenal cortex. This is the basis of the hypothalamus-pituitary-adrenal gland crosstalk, although CRH can also directly stimulate the release of CORT from adrenal gland (reviewed in [150]) as well as inhibit GnRH secretion in the rhesus monkey [151]. Moreover, the fact that CRH can also stimulate the TSH synthesis clearly shows how complex might be the crosstalk regulation of the reproduction through peripheral tissues (reviewed in [143]).

CORT acts on target tissues through mineralocorticoid receptor (MR) and glucocorticoid receptor (GR). Besides increasing blood glucose levels, acting on cardiovascular and immune system with anti-inflammatory properties, CORT is also involved in human and murine reproduction (reviewed in [152]). Increased adrenal CORT levels exert negative feedback through the inhibition of the entire HPG axis. At central level, it is known that CORT had an inhibitory effect on GnRH and LH release, whereas its potential effect on FSH results are somehow contradictory (reviewed in [153]). In male rats, stress-induced CORT release also has a direct inhibitory effect on testosterone synthesis in Leydig cells $[153,154]$, in addition to the impact at hypothalamic and pituitary level. At the mammalian ovary, CORT is known to exert both agonist and antagonist effects, since an increase of the basal CORT level during the ovulatory process is needed, whereas stress-induced CORT release inhibits $\mathrm{E}_{2}$ but increases $\mathrm{P}_{4}$ levels $[153,155]$.

Although significant levels of several K vitamers (particularly MK-4) were found in tissues, like mammalian thyroid and adrenal gland $[9,16]$, and $g g c x$, vkorc1 and vkorc1l1 were reported to be expressed in the adrenal gland of male and female mice [92], little is known regarding how VK might affect thyroid and adrenal hormones signaling. While PXR-regulated transcriptome is dependent on the nutritional status, affecting thyroid hormone metabolism II in mice [156], several studies have shown that PXR plays an important role in adrenal steroid hormone homeostasis. Activation of PXR markedly increases plasma concentrations of corticosterone and aldosterone, the primary glucocorticoid and mineralocorticoid in rodents, being associated to the activation of adrenal steroidogenic enzymes, including CYP11A1, CYP11B1, CYP11B2, and HSD3B2 [157]. In a vertebrate's model for developmental biology, the zebrafish, the exposure to warfarin during embryogenesis affect the thyrotropin-releasing hormone receptor signaling pathway, at least at the transcriptomic level [41], suggesting that the VK status might influence THs synthesis and homeostasis.

The pancreas-bone-testis axis communication is the most characterized tissue crosstalk by which VK might exert an important role in vertebrate's reproduction. At the pancreas, within the islets of Langerhans, $\beta$ cells produce insulin, an anabolic hormone, promoting carbon energy deposition in the body and participating in the control of glycemia [158]. A failing control of glycemia through insulin induce complications, such as neuropathy, nephropathy, retinopathy, vascular and bone disorders in vertebrates. Regarding the effects on skeletal tissue, humans with type 2 diabetes suffer higher fracture risk [159]. Indeed, insulin stimulates osteoblast differentiation favoring osteoclast bone resorption and generating and releasing undercarboxylated $\mathrm{OCN}$ in mouse models [50]. OCN is a VKDP shown to control bone mineralization, as demonstrated in OCN-deficient mice [160]. Once carboxylated, it has a high affinity for calcium and hydroxyapatite, the mineral component of the bone extracellular matrix [161], but, during bone remodeling, the acid $\mathrm{pH}$ produced by osteoclast favors its undercaboxylation status and release to circulation, enhancing male fertility (reviewed in [162]). $\mathrm{ocn}^{-/-}$ mice are poor breeders that are characterized by low testosterone levels, oligospermia and a reduced 
reproductive organ weight, a condition that can be reversed by OCN administration [163]. OCN may act on Leydig cells through the G protein-coupled receptor class c group 6 member (GPRC6A). Gprc6a $a^{-/-}$and $\mathrm{ocn}^{-/-}$mice have almost identical metabolic and reproductive phenotypes, including reduced testosterone levels and particularly, Leydig cell-specific deletion of GPRC6A (gprc6aLeydig+/-) leads to these reproductive defects in males [164]. OCN signaling regulates the expression of genes that are associated with testosterone production in a cAMP response element binding protein (CREB)-dependent manner, as demonstrated by CREB phosphorylation in osteocalcin-treated Leydig cells and corroborated in $\mathrm{Creb}_{\text {Leyding }}{ }^{-/}$mice [163]. Indeed, unOCN has been shown to activate GPRC6A using Docking simulation and in vitro assay with MA-10 and $\beta$-TC6 cell lines [165], inducing the PKA, PKC, PKG activation, as well as the $\mathrm{Ca}^{2+}$ release [115], driving the specific expression of star, cyp11a, cyp17, and $3 \beta$-hsd genes that are required for testosterone biosynthesis, and representing a complex pancreas-bone-testis axis communication (reviewed in [162,166]). Interestingly, it was recently found that this regulation through OCN was LH independent in Sprague-Dawley male rats [167]. Moreover, because PXR-deficient rodents had disrupted glucose homeostasis [168], a low transactivation of PXR due to VK deficiency might be an additional source of altered glucose homeostasis and thus, male reproductive disorders.

With the discovery of the key role of non-coding RNAs (ncRNAs) in cell biology, a diverse set of ncRNAs (e.g., micro-RNAs (miRs) and P-element-induced wimpy testis (PIWI)-interacting RNAs (piRs)) involved on vertebrate's reproduction as well as their corresponding DNA/mRNA target sequences were identified. A key role of piRs in male gametogenesis was clearly evidenced by the male sterility in mice lacking the piR pathway [169]. Similarly, different miRs have been shown to have great influence on cell mitosis during mammalian gametogenesis (reviewed in [170]). In fish species, like salmon, not only new specific miRs have been linked to testis maturation, but also a functional conservation in vertebrates of known miRs involved in the transition into puberty have been suggested [171]. Different clinical studies have been explored the use of miRs as potential biomarkers for human male factor infertility [104,172]. Furthermore, in humans, the presence of specific miRs (such as miR-31) in seminal plasma exosomes might be not only a suitable biomarker of azoospermia, but also a prognostic tool of embryo development [172]. In a recent study, dietary VK supplementation during six months in Senegalese sole not only increased testosterone plasma levels in both genders and improved male's sperm quality (above-mentioned), but also specific ncRNAs differentially expressed in blood plasma through RNA-Seq analysis were discovered [49]. In these males, a lower expression of miR-146 family members (miR146a-1-2-3 and miR-146a) and a higher of let-7 family members $($ let-7g, $-7 e$ (18 nt), -7a1, -7a-3,-7a-2,-7a-1,-7e (23 nt)) and piR-675//676//4794//5462 was found when compared to that of males fed the Control diet (with higher sperm DNA fragmentation). Both miR146 and let-7 family members are expressed in spermatogonia and only let-7s in spermatocytes, and oppositely involved in the RA-induced spermatogonia differentiation in mice [173,174]. A bioinformatic analysis predicted some genes involved in glycoprotein hormone $\alpha$-subunit synthesis and GnRH pathway (among other physiological processes), as mRNA targets of those ncRNAs, suggesting a further more complex regulation of reproduction in Senegalese sole males, and clearly associated with VK [49].

\section{Conclusions}

Fulfilling the dietary recommended intake (DRI) of each nutrient is basic for a proper development and health, and to complete all of the required biological functions, including reproduction. Furthermore, not covering the requirements for a particular nutrient may have deeper impact on the progeny, as it has been found for VK in different vertebrate species $[49,175]$. Knowledge on VK metabolites, metabolism, functions, and identification of suitable and accurate biomarkers is critical to identify the DRI for VK in vertebrates. Nowadays, VK DRI is based solely on the intake of vitamin $\mathrm{K} 1$ and the quantification of blood coagulation time and/or the uncarboxylated forms of BGP and MGP [24]. Based on the literature here reviewed, it seems more appropriated to define DRI considering biological process other than blood coagulation, including reproduction. Furthermore, taking into 
account the potential role of VK2 in neural and gonad development, a specific DRI on VK2 might be highly advisable as well as the use of different and specific biomarkers for fixing the nutritional requirements of VK in vertebrate's gametogenesis.

In particular, VK seems to have an impact on testosterone synthesis among other steroids, oxidative stress response, and osteocalcin signaling in gonads, as well as $\mathrm{GnRH}$, glutamate, and intracellular calcium levels and signaling at hypothalamus and pituitary tissues. While some classical biomarkers of gametogenesis, such as testosterone, LH, and FSH serum levels, are already available for determining the optimal VK dietary level for vertebrate's reproduction, a better understanding of the precise signaling pathways active in the organs, and tissues that are involved in the complex regulation of reproduction would allow a deeper and complete prediction of the effects elicited by VK nutritional status. Recent results on the potential cell-to-cell communication through circulating ncRNAs revealed an unexpected regulatory pathway, by which VK may exert a role on reproductive performance. Future research on this issue, as well as on the potential role of VK on thyroid and adrenal gland, might bring new light to understand the broad biological role of VK in vertebrates. Last, but not the least, we have recently shown as the use of fish teleosts is an interesting biological model in vertebrates to identify the effects and describe the conserved VK-related molecular pathways by which VK has a great impact, not only in blood coagulation and bone tissue, but also in reproduction. In this sense, the use of these species might help to unveil whether parental VK nutritional status might determine primordial germ cell population (PGCs), sex gender, gonad development, and/or reproductive performance on their progenies.

Author Contributions: Conceptualization, I.F.; writing—original draft preparation, S.B., F.J.T.-S. and I.F.; writing—review and editing, S.B., F.J.T.-S. and I.F.; funding acquisition, I.F. All authors have read and agreed to the published version of the manuscript.

Funding: This research was funded by MET2VI project (Ref. RTI2018-099029-A-I00) funded by the European Regional Development Fund (ERDF)—Ministerio de Ciencia, Innovación y Universidades (MICIU)—Agencia Estatal de Investigación of the Spanish Government. F.J.T.S. acknowledges the funding from the Mexican National Council for Science and Technology (CONACYT) for the postdoctoral fellowship No. 2019-000012-01EXTV-00292. I.F. acknowledges the funding from the MICIU and the European Social Fund, "The European Social Fund invests in your future" through the Ramón y Cajal (Ref. RYC2018-025337-I) contract from the Plan Estatal de Investigación Científica y Técnica e Innovación 2017-2020.

Conflicts of Interest: The authors declare no conflict of interest.

\section{References}

1. Fernández, I.; Gavaia, P.; Darias, M.J.; Gisbert, E. Fat-soluble vitamins in fish: A transcriptional tissue-specific crosstalk that remains to be unveiled and characterized. In Emerging Issues in Fish Larvae Research; Yúfera, M., Ed.; Springer International Publishing: Cham, Switzerland, 2018; pp. 159-208.

2. Harshman, S.G.; Saltzman, E.; Booth, S.L. Vitamin K: Dietary intake and requirements in different clinical conditions. Curr. Opin. Clin. Nutr. Metab. Care. 2014, 17, 438-531. [CrossRef] [PubMed]

3. Lambert, W.E.; De Leenher, A.P. Vitamin K. In Modern Chromatographic Analysis of Vitamins, 2nd ed.; De Leenher, A.P., Lamberts, W.E., Nelis, H.J., Eds.; Marcel Dekker: New York, NY, USA, 1992; Volume 84, pp. 214-251.

4. Booth, S.L.; Suttie, J.W. Dietary intake and adequacy of vitamin K. J. Nutr. 1998, 128, 785-788. [CrossRef] [PubMed]

5. Fodor, D.; Albu, A.; Poanta, L.; Porojan, M. Vitamin K and vascular calcifications. Acta Physiol. Hung. 2010, 97, 256-266. [CrossRef]

6. Sobinoff, A.P.; Pye, V.; Nixon, B.; Roman, S.D.; McLaughlin, E.A. Adding insult to injury: Effects of xenobiotic-induced preantral ovotoxicity on ovarian development and oocyte fusibility. Toxicol. Sci. 2010, 118, 653-666. [CrossRef] [PubMed]

7. Food, E.; Authority, S. Scientific opinion on the safety and efficacy of vitamin K3 (menadione sodium bisulphite and menadione nicotinamide bisulphite) as a feed additive for all animal species. EFSA J. 2014, 12. 
8. Nakagawa, K.; Hirota, Y.; Sawada, N.; Yuge, N.; Watanabe, M.; Uchino, Y.; Okuda, N.; Shimomura, Y.; Suhara, Y.; Okano, T. Identification of UBIAD1 as a novel human menaquinone-4 biosynthetic enzyme. Nature 2010, 468, 117-121. [CrossRef]

9. Shearer, M.J.; Okano, T. Key pathways and regulators of vitamin K function and intermediary metabolism. Annu. Rev. Nutr. 2018, 38, 127-151. [CrossRef]

10. Kohlmeier, M.; Salomon, A.; Saupe, J.; Shearer, M.J. Transport of vitamin K to bone in Humans. J. Nutr. 1996, 126, 1192S-1196S. [CrossRef]

11. Hirota, Y.; Tsugawa, N.; Nakagawa, K.; Suhara, Y.; Tanaka, K.; Uchino, Y.; Takeuchi, A.; Sawada, N.; Kamao, M.; Wada, A.; et al. Menadione (Vitamin K3) is a catabolic product of oral phylloquinone (vitamin K1) in the intestine and a circulating precursor of tissue menaquinone-4 (vitamin K2) in rats. Int. J. Biol. Chem. 2013, 288, 33071-33080. [CrossRef]

12. Thijssen, H.H.; Vervoort, L.M.; Schurgers, L.J.; Shearer, M.J. Menadione is a metabolite of oral vitamin K. Br. J. Nutr. 2006, 95, 260-266. [CrossRef]

13. Funahashi, N.; Hirota, Y.; Nakagawa, K.; Sawada, N.; Watanabe, M.; Suhara, Y.; Okano, T. YY1 Positively regulates human UBIAD1 expression. Biochem. Biophys. Res. Commun. 2015, 460, $238-244$. [CrossRef] [PubMed]

14. Jo, Y.; Kim, S.S.; Garland, K.; Fuentes, I.; DiCarlo, L.M.; Ellis, J.L.; Fu, X.; Booth, S.L.; Evers, B.M.; DeBose-Boyd, R.A. Enhanced ER-associated degradation of HMG CoA reductase causes embryonic lethality associated with Ubiad1 deficiency. eLife 2020, 9, e54841. [CrossRef] [PubMed]

15. World Health Organization. Vitamin and mineral requirements in human nutrition Second Edition; World Health Organization: Geneva, Switzerland, 1998; pp. 1-20. ISBN 9241546123.

16. Ferland, G.; Doucet, I.; Mainville, D. Phylloquinone and menaquinone-4 tissue distribution at different life stages in male and female Sprague-Dawley rats fed different VK levels sinceweaning or subjected to a $40 \%$ calorie restriction since adulthood. Nutrients 2016, 8, 141. [CrossRef]

17. Tabb, M.M.; Sun, A.; Zhou, C.; Grun, F.; Errandi, J.L.; Romero, K.M.; Pham, H.; Inoue, S.; Mallick, S.; Lin, M.; et al. Vitamin $\mathrm{K} 2$ regulation of bone homeostasis is mediated by the steroid and xenobiotic receptor, SXR. J. Biol. Chem. 2003, 278, 43919-43927. [CrossRef]

18. Lamba, V.; Yasuda, K.; Lamba, J.K.; Assem, M.; Davila, J.; Strom, S.; Schuetz, E.G. PXR (NR1I2): Splice variants in human tissues, including brain, and identification of neurosteroids and nicotine as PXR activators. Toxicol. Appl. Pharmacol. 2004, 199, 251-265. [CrossRef]

19. Azuma, K.; Casey, S.C.; Ito, M.; Urano, T.; Horie, K.; Ouchi, Y.; Kirchner, S.; Blumberg, B.; Inoue, S. Pregnane $\mathrm{X}$ receptor knockout mice display osteopenia with reduced bone formation and enhanced bone resorption. J. Endocrinol. 2010, 207, 257-263. [CrossRef]

20. Marques, C.; Roberto, V.P.; Granadeiro, L.; Trindade, M.; Gavaia, P.J.; Laizé, V.; Cancela, M.L.; Fernández, I. The xenobiotic sensor PXR in a marine flatfish species (Solea senegalensis): Gene expression patterns and its regulation under different physiological conditions. Mar. Environ. Res. 2017, 130, 187-199. [CrossRef]

21. Shearer, M.J. Vitamin K | Physiology. In Encyclopedia of Food Sciences and Nutrition (Second Edition); Caballero, B., Ed.; Academic Press: Cambridge, MA, USA, 2003; pp. 6039-6045. ISBN 9780122270550. [CrossRef]

22. Krossoy, C.; Waagbo, R.; Fjelldal, P.G.; Wargelius, A.; Lock, E.J.; Graff, I.E.; Ornsrund, R. Dietary menadione nicotinamide bisulphite (vitamin K3) does not affect growth or bone health in first feeding fry of Atlantic salmon (Salmo salar L.). Aquac. Nutr. 2009, 15, 638-649. [CrossRef]

23. Thijssen, H.H.; Drittij-Reijnders, M.J.; Fischer, M.A. Phylloquinone and menaquinone- 4 distribution in rats: Synthesis rather than uptake determines menaquinone-4 organ concentrations. J. Nutr. 1996, 126, 537-543. [CrossRef]

24. Halder, M.; Petsophonsakul, P.; Akbulut, A.C.; Pavlic, A.; Bohan, F.; Anderson, E.; Maresz, K.; Kramann, R.; Schurgers, L. Vitamin K: Double bonds beyond coagulation insights into differences between vitamin K1 and K2 in health and disease. Int. J. Mol. Sci. 2019, 20, 896. [CrossRef] [PubMed]

25. Beulens, J.W.J.; Booth, S.L.; Van Den Heuvel, E.G.H.M.; Stoecklin, E.; Baka, A.; Vermeer, C. The role of menaquinones (vitamin K2) in human health. Br. J. Nutr. 2013, 110, 1357-1368. [CrossRef] [PubMed]

26. Shea, M.K.; Booth, S.L.; Nettleton, J.A.; Burke, G.L.; Chen, H.; Kritchevsky, S.B. Circulating phylloquinone concentrations of adults in the united states differ according to race and ethnicity. J. Nutr. 2012, 142, 1060-1066. [CrossRef] [PubMed] 
27. Westerman, K.; Kelly, J.M.; Ordovás, J.M.; Booth, S.L.; De Meo, D.L. Epigenome-Wide association study reveals a molecular signature of response to phylloquinone (vitamin K1) supplementation. Epigenetics 2020, 15, 859-870. [CrossRef]

28. Harshman, S.G.; Shea, M.K. The role of Vitamin K in chronic aging diseases: Inflammation, cardiovascular disease, and osteoarthritis. Curr. Nutr. Rep. 2016, 5, 90-98. [CrossRef]

29. Lacombe, J.; Ferron, M. VKORC1L1, an enzyme mediating the effect of vitamin K in liver and extrahepatic tissues. Nutrients 2018, 10,970. [CrossRef]

30. Lacombe, J.; Rishavy, M.A.; Berkner, K.L.; Ferron, M. VKOR paralog VKORC1L1 supports vitamin K-dependent protein carboxylation in vivo. JCI Insight 2018, 3, 1-11. [CrossRef]

31. Beato, S.; Marques, C.; Laizé, V.; Gavaia, P.J.; Fernández, I. New insights on vitamin K metabolism in Senegalese sole (Solea Senegalensis) based on ontogenetic and tissue-specific vitamin K epoxide reductase molecular data. Int. J. Mol. Sci. 2020, 21, 3489. [CrossRef]

32. Finnan, E.G.; Harshman, S.G.; Haytowitz, D.B.; Booth, S.L. Mixed dishes are an unexpected source of dietary Vitamin K. J. Food Compos. Anal. 2017, 64, 127-131. [CrossRef]

33. Turck, D.; Bresson, J.; Burlingame, B.; Dean, T.; Fairweather-Tait, S.; Heinonen, M.; Hirsch-Ernst, K.I.; Mangelsdorf, I.; McArdle, H.J.; Naska, A.; et al. Dietary reference values for vitamin K. EFSA J. 2017, 15, 1-78. [CrossRef]

34. Shea, M.K.; Booth, S.L. Concepts and controversies in evaluating vitamin K status in population-based studies. Nutrients 2016, 8, 8. [CrossRef] [PubMed]

35. Zhu, A.; Sun, H.; Raymond, R.M.; Furie, B.C.; Furie, B.; Bronstein, M.; Kaufman, R.J.; Westrick, R.; Ginsburg, D. Fatal hemorrhage in mice lacking $\gamma$-Glutamyl carboxylase. Blood 2007, 109, 5270-5275. [CrossRef] [PubMed]

36. Berkner, K.L. Vitamin K-Dependent Carboxylation. Vitam. Horm. 2008, 78, 131-156. [CrossRef]

37. Fernández, I.; Santos, A.; Cancela, M.L.; Laizé, V.; Gavaia, P.J. Warfarin, a potential pollutant in aquatic environment acting through Pxr signaling pathway and $\gamma$-glutamyl carboxylation of vitamin K-dependent proteins. Environ. Pollut. 2014, 194, 86-95. [CrossRef] [PubMed]

38. Atkins, J.G.; Welldon, J.K.; Wijenayaka, R.A.; Bonewald, F.L.; Findlay, M.D. Vitamin K promotes mineralization, osteoblast-to-osteocyte transition, and an anticatabolic phenotype by $\gamma$-carboxylation-dependent and -independent mechanisms. Am. J. Physiol. Cell Physiol. 2009, 297, C1358-C1367. [CrossRef] [PubMed]

39. Richard, N.; Fernández, I.; Wulff, T.; Hamre, K.; Cancela, L.; Conceição, L.E.; Gavaia, P.J. Dietary supplementation with vitamin $\mathrm{K}$ affects transcriptome and proteome of Senegalese sole, improving larval performance and quality. Mar. Biotechnol. 2014, 16, 522-537. [CrossRef]

40. Cardeira, J.; Gavaia, P.J.; Fernández, I.; Cengiz, I.F.; Moreira-Silva, J.; Oliveira, J.M.; Reis, R.L.; Cancela, M.L.; Laizé, V. Quantitative assessment of the regenerative and mineralogenic performances of the zebrafish caudal fin. Sci. Rep. 2016, 6. [CrossRef]

41. Granadeiro, L.; Dirks, R.P.; Ortiz-Delgado, J.B.; Gavaia, P.J.; Sarasquete, C.; Laizé, V.; Cancela, M.L.; Fernández, I. Warfarin-exposed zebrafish embryos resembles human warfarin embryopathy in a dose and developmental-time dependent manner - From molecular mechanisms to environmental concerns. Ecotox. Environ. Saf. 2019, 181, 559-571. [CrossRef]

42. Shea, M.K.; Booth, S.L.; Harshman, S.G.; Smith, D.; Carlson, C.S.; Harper, L.; Armstrong, A.R.; Fang, M.; Cancela, M.L.; Simão, M.; et al. The effect of vitamin K insufficiency on histological and structural properties of knee joints in aging mice. Osteoarthr. Cartil. Open 2020, 100078. [CrossRef]

43. Schurgers, L.J.; Uitto, J.; Reutelingsperger, C.P. Vitamin K-dependent carboxylation of matrix gla-protein: A crucial switch to control ectopic mineralization. Trends Mol. Med. 2013, 19, 217-226. [CrossRef]

44. Nowak, J.K.; Grzybowska-Chlebowczyk, U.; Landowski, P.; Szaflarska-Poplawska, A.; Klincewicz, B.; Adamczak, D.; Banasiewicz, T.; Plawski, A.; Walkowiak, J. Prevalence and correlates of vitamin K deficiency in children with inflammatory bowel disease. Sci. Rep. 2014, 4, 3-6. [CrossRef] [PubMed]

45. Scheiber, D.; Veulemans, V.; Horn, P.; Chatrou, M.L.; Potthoff, S.A.; Kelm, M.; Schurgers, L.J.; Westenfeld, R. High-dose menaquinone-7 supplementation reduces cardiovascular calcification in a murine model of extraosseous calcification. Nutrients 2015, 7, 6991-7011. [CrossRef] [PubMed]

46. Westhofen, P.; Watzka, M.; Marinova, M.; Hass, M.; Kirfel, G.; Muller, J.; Bevans, C.G.; Muller, C.R.; Oldenburg, J. Human vitamin K 2,3-Epoxide reductase complex subunit 1-like 1 (VKORC1L1) mediates vitamin K-Dependent intracellular antioxidant function. J. Biol. Chem. 2011, 286, 15085-15094. [CrossRef] 
47. Sidorova, Y.A.; Perepechaeva, M.L.; Pivovarova, E.N.; Markel, A.L.; Lyakhovich, V.V.; Grishanova, A.Y. Menadione suppresses benzo( $\alpha$ )pyrene-induced activation of cytochromes P450 1A: Insights into a possible molecular mechanism. PLOS ONE 2016, 11, 1-17. [CrossRef]

48. Ferland, G. Vitamin K, an emerging nutrient in brain function. Biofactors 2012, 38, 151-157. [CrossRef]

49. Fernández, I.; Fernandes, J.M.O.; Roberto, V.P.; Kopp, M.; Oliveira, C.; Riesco, M.F.; Dias, J.; Cox, C.J.; Leonor-Cancela, M.; Cabrita, E.; et al. Circulating small non-coding RNAs provide new insights into vitamin K nutrition and reproductive physiology in teleost fish. Biochim. Biophys. Acta Gen Subj. 2019, 1863, 39-51. [CrossRef]

50. Karsenty, G.; Ferron, M. The contribution of bone to whole-organism physiology. Nature 2012, 481, 314-320. [CrossRef]

51. Alisi, L.; Cao, R.; De Angelis, C.; Cafolla, A.; Caramia, F.; Cartocci, G.; Librando, A.; Fiorelli, M. The relationships between vitamin $\mathrm{k}$ and cognition: A review of current evidence. Front. Neurol. 2019, 10, 1-9. [CrossRef]

52. Hirota, Y.; Suhara, Y. New aspects of vitamin K research with synthetic ligands: Transcriptional activity via SXR and neural differentiation activity. Int. J. Mol. Sci. 2019, 20, 3006. [CrossRef] [PubMed]

53. Saghiri, M.A.; Asatourian, A.; Ershadifar, S.; Moghadam, M.M.; Sheibani, N. Vitamins and regulation of angiogenesis: [A, B1, B2, B3, B6, B9, B12, C, D, E, K]. J. Funct. Foods 2017, 38, 180-196. [CrossRef]

54. Shirakawa, H.; Ohsaki, Y.; Minegishi, Y.; Takumi, N.; Ohinata, K.; Furukawa, Y.; Mizutani, T.; Komai, M. Vitamin K deficiency reduces testosterone production in the testis through down-regulation of the Cyp11a a cholesterol side chain cleavage enzyme in rats. Biochim. Biophys. Acta. 2006, 1760, 1482-1488. [CrossRef] [PubMed]

55. Ito, A.; Shirakawa, H.; Takumi, N.; Minegishi, Y.; Ohashi, A.; Howlader, Z.H.; Ohsaki, Y.; Sato, T.; Goto, T.; Komai, M. Menaquinone-4 enhances testosterone production in rats and testis-derived tumor cells. Lipids Health Dis. 2011, 10. [CrossRef] [PubMed]

56. Fernández, I.; Vijayakumar, P.; Marques, C.; Cancela, M.L.; Gavaia, P.J.; Laizé, V. Zebrafish vitamin K epoxide reductases: Expression in vivo, along extracellular matrix mineralization and under phylloquinone and warfarin in vitro exposure. Fish Physiol. Biochem. 2015, 41, 745-759. [CrossRef] [PubMed]

57. Bevans, C.G.; Krettler, C.; Reinhart, C.; Watzka, M.; Oldenburg, J. Phylogeny of the vitamin K 2,3-Epoxide Reductase (VKOR) family and evolutionary relationship to the disulfide bond formation protein B (DsbB) family. Nutrients 2015, 7, 6224-6249. [CrossRef]

58. Oldenburg, J.; Watzka, M.; Bevans, C.G. VKORC1 and VKORC1L1: Why do vertebrates have two vitamin K 2,3-epoxide reductases? Nutrients 2015, 7, 6250-6280. [CrossRef]

59. Wallace, B.D.; Betts, L.; Talmage, G.; Pollet, R.M.; Holman, N.S.; Redinbo, M.R. Structural and functional analysis of the human nuclear xenobiotic receptor PXR in complex with RXRa. J. Mol. Biol. 2013, 425, 2561-2577. [CrossRef]

60. Hammed, A.; Matagrin, B.; Spohn, G.; Prouillac, C.; Benoit, E.; Lattard, V. VKORC1L1, an enzyme rescuing the vitamin K 2,3-Epoxide reductase activity in some extrahepatic tissues during anticoagulation therapy. J. Biol. Chem. 2013, 288, 28733-28742. [CrossRef]

61. Rishavy, M.A.; Hallgren, K.W.; Wilson, L.A.; Usubalieva, A.; Runge, K.W.; Berkner, K.L. The vitamin K oxidoreductase is a multimer that efficiently reduces vitamin k epoxide to hydroquinone to allow vitamin K-dependent protein carboxylation. J. Biol. Chem. 2013, 288, 31556-31566. [CrossRef]

62. Oldenburg, J.; Marinova, M.; Müller-Reible, C.; Watzka, M. The vitamin K cycle. Vitam. Horm. 2008, 78, 35-62. [CrossRef]

63. Tie, J.K.; Stafford, D.W. Structural and functional insights into enzymes of the vitamin K cycle. J. Thromb. Haemost. 2016, 14, 236-247. [CrossRef]

64. Kulman, J.D.; Harris, J.E.; Nakazawa, N.; Ogasawara, M.; Satake, M.; Davie, E.W. Vitamin K-dependent proteins in Ciona intestinalis, a basal chordate lacking a blood coagulation cascade. Proc. Natl. Acad. Sci. USA 2006, 103, 15794-15799. [CrossRef]

65. Li, T.; Yang, C.T.; Jin, D.; Stafford, D.W. Identification of a drosophila vitamin K-dependent $\gamma$-Glutamyl Carboxylase. J. Biol. Chem. 2000, 275, 18291-18296. [CrossRef] [PubMed]

66. Bandyopadhyay, P.K.; Garrett, J.E.; Shetty, R.P.; Keate, T.; Walker, C.S.; Olivera, B.M. $\gamma$-Glutamyl Carboxylation: An extracellular posttranslational modification that antedates the divergence of molluscs, arthropods, and chordates. Proc. Natl. Acad. Sci. USA 2002, 99, 1264-1269. [CrossRef] 
67. Wen, L.; Chen, J.; Duan, L.; Li, S. Vitamin K-Dependent proteins involved in bone and cardiovascular health. Mol. Med. Rep. 2018, 18, 3-15. [CrossRef]

68. Spohn, G.; Kleinridders, A.; Wunderlich, F.T.; Watzka, M.; Zaucke, F.; Blumbach, K.; Geisen, C.; Seifried, E.; Müller, C.; Paulsson, M.; et al. VKORC1 deficiency in mice causes early postnatal lethality due to severe bleeding. Thromb. Haemost. 2009, 101, 1044-1050. [CrossRef] [PubMed]

69. Chatron, N.; Chalmond, B.; Trouvé, A.; Benoît, E.; Caruel, H.; Lattard, V.; Tchertanov, L. Identification of the functional states of human vitamin $\mathrm{K}$ epoxide reductase from molecular dynamics simulations. RSC Adv. 2017, 7, 52071-52090. [CrossRef]

70. Willson, T.M.; Kliewer, S.A. PXR, CAR and drug metabolism. Nat. Rev. Drug Discov. 2002, 1, 259-266. [CrossRef]

71. Ekins, S.; Reschly, E.J.; Hagey, L.R.; Krasowski, M.D. Evolution of pharmacologic specificity in the pregnane $\mathrm{X}$ receptor. BMC Evol. Pharmacol. 2008, 8, 103. [CrossRef]

72. Salanga, M.C.; Brun, N.R.; Francolini, R.D.; Stegeman, J.J.; Goldstone, J.V. CRISPR-Cas9-Mutated pregnane $\mathrm{X}$ receptor (pxr) retains pregnenolone-induced expression of cyp3a65 in Zebrafish (Danio rerio) larvae. Toxicol. Sci. 2020, 174, 51-62. [CrossRef]

73. Cui, W.; Sun, M.; Zhang, S.; Shen, X.; Galeva, N.; Williams, T.D.; Staudinger, J.L.A. SUMO-Acetyl switch in PXR biology. Biochim. Biophys. Acta - Gene Regul. Mech. 2016, 1859, 1170-1182. [CrossRef]

74. Rulcova, A.; Prokopova, I.; Krausova, L.; Bitman, M.; Vrzal, R.; Dvorak, Z.; Blahos, J.; Pavek, P. Stereoselective interactions of warfarin enantiomers with the pregnane $\mathrm{X}$ nuclear receptor in gene regulation of major drug-metabolizing cyto- chrome P450 enzymes. J. Thromb. Haemost. 2010, 8, 2708-2717. [CrossRef]

75. Cui, J.Y.; Klaassen, C.D. RNA-Seq reveals common and unique PXR- and CAR-Target gene signatures in the mouse liver transcriptome. Biochim. Biophys. Acta - Gene Regul. Mech. 2016, 1859, 1198-1217. [CrossRef]

76. Pavek, P. Pregnane X receptor (PXR)-mediated gene repression and cross-talk of PXR with other nuclear receptors via coactivator interactions. Front. Pharmacol. 2016, 7. [CrossRef] [PubMed]

77. Torres-Vergara, P.; Ho, Y.S.; Espinoza, F.; Nualart, F.; Escudero, C.; Penny, J. The constitutive androstane receptor and pregnane $X$ receptor in the brain. Br. J. Pharmacol. 2020, 177, 2666-2682. [CrossRef]

78. Bertrand, S.; Thisse, B.; Tavares, R.; Sachs, L.; Chaumot, A.; Bardet, P.; Escrivà, H.; Duffraisse, M.; Marchand, O.; Safi, R.; et al. Unexpected novel relational links uncovered by extensive developmental profiling of nuclear receptor expression. PLoS Genet. 2007, 3, e188. [CrossRef] [PubMed]

79. Gräns, J.; Wassmur, B.; Fernández-Santoscoy, M.; Zanette, J.; Woodin, B.R.; Karchner, S.I.; Nacci, D.E.; Champlin, D.; Jayaraman, S.; Hahn, M.E.; et al. Regulation of pregnane-X-receptor, CYP3A and P-glycoprotein genes in the PCB-resistant killifish (Fundulus heteroclitus) population from New Bedford Harbor. Aquat. Toxicol. 2015, 159, 198-207. [CrossRef] [PubMed]

80. Bainy, A.C.D.; Kubota, A.; Goldstone, J.V.; Lille-Langøy, R.; Karchner, S.I.; Celander, M.C.; Hahn, M.E.; Goksøyr, A.; Stegeman, J.J. Functional characterization of a full length pregnane X receptor, expression in vivo, and identification of PXR alleles, in zebrafish (Danio Rerio). Aquat. Toxicol. 2013, 142-143, 447-457. [CrossRef] [PubMed]

81. Kornbluth, S.; Fissore, R. Vertebrate reproduction. Cold Spring Harb. Perspect. Biol. 2015, 7, 1-18. [CrossRef] [PubMed]

82. Mosconi, G.; Carnevali, O.; Franzoni, M.F.; Cottone, E.; Lutz, I.; Kloas, W.; Yamamoto, K.; Kikuyama, S.; Polzonetti-Magni, A.M. Environmental estrogens and reproductive biology in amphibians. Gen. Comp. Endocrinol. 2002, 126, 125-129. [CrossRef]

83. Giesy, J.P.; Lori, A.F.; Jones, P.D.; Kannan, K.; Sanderson, T. Review of the effects of endocrine-disrupting chemicals in birds. Pure Appl. Chem. 2003, 75, 2287-2303. [CrossRef]

84. Hong, J.; Chen, F.; Wang, X.; Bai, Y.; Zhou, R.; Li, Y.; Chen, L. Exposure of preimplantation embryos to low-dose bisphenol A impairs testes development and suppresses histone acetylation of StAR promoter to reduce production of testosterone in mice. Mol. Cell. Endocrinol. 2016, 427, 101-111. [CrossRef] [PubMed]

85. Forner-Piquer, I.; Beato, S.; Piscitelli, F.; Santangeli, S.; Di Marzo, V.; Habibi, H.R.; Maradonna, F.; Carnevali, O. Effects of BPA on zebrafish gonads: Focus on the endocannabinoid system. Environ. Pollut. 2020, 264. [CrossRef] [PubMed]

86. Almawi, W.Y.; Al-Shaikh, F.S.; Melemedjian, O.K.; Almawi, A.W. Protein Z, an anticoagulant protein with expanding role in reproductive biology. Reproduction 2013, 146, R73-R80. [CrossRef] [PubMed] 
87. Sofikitis, N.; Giotitsas, N.; Tsounapi, P.; Baltogiannis, D.; Giannakis, D.; Pardalidis, N. Hormonal regulation of spermatogenesis and spermiogenesis. J. Steroid Biochem. Mol. Biol. 2008, 109, 323-330. [CrossRef]

88. Schulz, R.W.; De França, L.R.; Lareyre, J.J.; Le Gac, F.; Chiarini-Garcia, H.; Nobrega, R.H.; Miura, T. Spermatogenesis in fish. Gen. Comp. Endocrinol. 2010, 165, 390-411. [CrossRef]

89. Chen, S.R.; Liu, Y.X. Regulation of spermatogonial stem cell self-renewal and spermatocyte meiosis by sertoli cell signaling. Reproduction 2015, 149, R159-R167. [CrossRef]

90. Tovo-Neto, A.; Da Silva Rodrigues, M.; Habibi, H.R.; Nóbrega, R.H. Thyroid hormone actions on male reproductive system of teleost fish. Gen. Comp. Endocrinol. 2018, 265, 230-236. [CrossRef]

91. Smith, L.B.; Walker, W.H. The regulation of spermatogenesis by androgens. Semin. Cell Dev. Biol. 2014, 30, 2-13. [CrossRef]

92. Caspers, M.; Czogalla, K.J.; Liphardt, K.; Müller, J.; Westhofen, P.; Watzka, M.; Oldenburg, J. Two enzymes catalyze vitamin $\mathrm{K}$ 2,3-Epoxide reductase activity in mouse: VKORC1 is highly expressed in exocrine tissues while VKORC1L1 is highly expressed in brain. Thromb. Res. 2015, 135, 977-983. [CrossRef]

93. Brewer, C.T.; Chen, T. PXR Variants: The impact on drug metabolism and therapeutic responses. Acta Pharm. Sin. B 2016, 6, 441-449. [CrossRef]

94. Wassmur, B.; Gräns, J.; Kling, P.; Celander, M.C. Interactions of pharmaceuticals and other xenobiotics on hepatic pregnane $\mathrm{X}$ receptor and cytochrome $\mathrm{P} 450$ 3A signaling pathway in rainbow trout (Oncorhynchus mykiss). Aquat Toxicol. 2010, 100, 91-100. [CrossRef] [PubMed]

95. Bailey, I.; Gibson, G.G.; Plant, K.; Graham, M.; Plant, N. A PXR-Mediated negative feedback loop attenuates the expression of CYP3A in response to the PXR agonist pregnenalone-16 $\alpha$-Carbonitrile. PLoS ONE 2011, 6, e16703. [CrossRef]

96. Frye, C.A.; Koonce, C.J.; Walf, A.A. Novel receptor targets for production and action of allopregnanolone in the central nervous system: A focus on pregnane xenobiotic receptor. Front. Cell. Neurosci. 2014, 8, 1-13. [CrossRef] [PubMed]

97. Ihunnah, C.A.; Jiang, M.; Xie, W. Nuclear receptor PXR, transcriptional circuits and metabolic relevance. Biochim. Biophys. Acta-Mol. Basis Dis. 2011, 1812, 956-963. [CrossRef] [PubMed]

98. Niwa, T.; Yabusaki, Y.; Honma, K.; Matsuo, N.; Tatsuta, K.; Ishibashi, F.; Katagiri, M. Contribution of human hepatic cytochrome P450 isoforms to regioselective hydroxylation of steroid hormones. Xenobiotica 1998, 28, 539-547. [CrossRef] [PubMed]

99. Gray, M.A.; Squires, E.J. Effects of nuclear receptor transactivation on boar taint metabolism and gene expression in porcine hepatocytes. J. Steroid Biochem. Mol. Biol. 2013, 133, 110-119. [CrossRef]

100. Sanyaolu, A.O.; Oremosu, A.A.; Osinubi, A.A.; Vermeer, C.; Daramola, A.O. Warfarin-induced vitamin K deficiency affects spermatogenesis in Sprague-Dawley rats. Andrologia 2019, 51, 1-9. [CrossRef]

101. Bisht, S.; Faiq, M.; Tolahunase, M.; Dada, R. Oxidative stress and male infertility. Nat. Rev. Urol. 2017, 14, 470-485. [CrossRef]

102. Yuan, J.; Feng, L.; Jiang, W.D.; Liu, Y.; Jiang, J.; Li, S.H.; Kuang, S.Y.; Tang, L.; Zhou, X.Q. Effects of dietary vitamin $\mathrm{K}$ levels on growth performance, enzyme activities and antioxidant status in the hepatopancreas and intestine of juvenile jian carp (Cyprinus Carpio Var. Jian). Aquac. Nutr. 2016, 22, 352-366. [CrossRef]

103. Czogalla, K.J.; Liphardt, K.; Höning, K.; Hornung, V.; Biswas, A.; Watzka, M.; Oldenburg, J. VKORC1 and VKORC1L1 have distinctly different oral anticoagulant dose-response characteristics and binding sites. Blood Adv. 2018, 2, 691-702. [CrossRef] [PubMed]

104. Kotaja, N. MicroRNAs and spermatogenesis. Fertil. Steril. 2014, 101, 1552-1562. [CrossRef] [PubMed]

105. Machtinger, R.; Laurent, L.C.; Baccarelli, A.A. Extracellular vesicles: Roles in gamete maturation, fertilization and embryo implantation. Hum. Reprod. Update 2016, 22, 182-193. [CrossRef] [PubMed]

106. Edson, M.A.; Nagaraja, A.K.; Matzuk, M.M. The mammalian ovary from genesis to revelation. Endocr. Rev. 2009, 30, 624-712. [CrossRef] [PubMed]

107. Bertoldo, M.J.; Walters, K.A.; Ledger, W.L.; Gilchrist, R.B.; Mermillod, P.; Locatelli, Y. In-vitro regulation of primordial follicle activation: Challenges for fertility preservation strategies. Reprod. Biomed. Online 2018, 36, 491-499. [CrossRef]

108. Li, Y.; Fang, Y.; Liu, Y.; Yang, X. MicroRNAs in ovarian function and disorders. J. Ovarian Res. $2015,8,51$. [CrossRef] [PubMed]

109. Luderer, U. Ovarian toxicity from reactive oxygen species. Vitam. Horm. 2014, 94, 99-127. [CrossRef] [PubMed] 
110. Tilly, J.L.; Tilly, K.I. Inhibitors of oxidative stress mimic the ability of follicle-stimulating hormone to suppress apoptosis in cultured rat ovarian follicles. Endocrinology 1995, 136, 242-252. [CrossRef]

111. Burstyn-Cohen, T. TAM receptor signaling in development. Int. J. Dev. Biol. 2017, 61, $215-224$. [CrossRef] [PubMed]

112. Saedi, S.; Khoradmehr, A.; Mohammad Reza, J.S.; Tamadon, A. The role of neuropeptides and neurotransmitters on Kisspeptin/Kiss1r-Signaling in female reproduction. J. Chem. Neuroanat. 2018, 92, 71-82. [CrossRef]

113. Stamatiades, G.A.; Kaiser, U.B. Gonadotropin regulation by pulsatile GnRH: Signaling and gene expression. Mol. Cell Endocrinol. 2018, 463, 131-141. [CrossRef]

114. Fallah, H.P.; Rodrigues, M.S.; Corchuelo, S.; Nóbrega, R.H.; Habibi, H.R. Role of GnRH isoforms in paracrine/autocrine control of zebrafish (Danio rerio) spermatogenesis. Endocrinology 2020, 161, bqaa004. [CrossRef] [PubMed]

115. Tremblay, J.J. Molecular regulation of steroidogenesis in endocrine leydig cells. Steroids 2015, 103, 3-10. [CrossRef] [PubMed]

116. Walker, W.H.; Cheng, J. FSH and testosterone signaling in sertoli cells. Reproduction 2005, 130, 15-28. [CrossRef] [PubMed]

117. Tilbrook, A.J.; Clarke, I.J. Negative feedback regulation of the secretion and actions of gonadotropin-releasing hormone in males. Biol. Reprod. 2001, 64, 735-742. [CrossRef]

118. Chimento, A.; Sirianni, R.; Casaburi, I.; Pezzi, V. Role of estrogen receptors and G protein-coupled estrogen receptor in regulation of hypothalamus-pituitary-testis axis and spermatogenesis. Front. Endocrinol. 2014, 5, 1-8. [CrossRef]

119. Iwasa, T.; Matsuzaki, T.; Yano, K.; Yanagihara, R.; Mayila, Y.; Irahara, M. The effects of chronic testosterone administration on hypothalamic gonadotropin-releasing hormone regulatory factors (Kiss1, NKB, pDyn and RFRP) and their receptors in female rats. Gynecol. Endocrinol. 2017, 34, 437-441. [CrossRef]

120. He, W.; Li, X.; Adekunbi, D.; Liu, Y.; Long, H.; Wang, L.; Lyu, Q.; Kuang, Y.; O’Byrne, K.T. Hypothalamic effects of progesterone on regulation of the pulsatile and surge release of luteinising hormone in female rats. Sci. Rep. 2017, 7, 1-11. [CrossRef]

121. Acevedo-Rodriguez, A.; Kauffman, A.S.; Cherrington, B.D.; Borges, C.S.; Roepke, T.A.; Laconi, M. Emerging insights into hypothalamic-pituitary-gonadal axis regulation and interaction with stress signalling. J. Neuroendocrinol. 2018, 30, e12590. [CrossRef]

122. Kirilov, M.; Clarkson, J.; Liu, X.; Roa, J.; Campos, P.; Porteous, R.; Schütz, G.; Herbison, A.E. Dependence of fertility on kisspeptin-Gpr54 signaling at the GnRH neuron. Nat Commun. 2013, 4, 2492. [CrossRef]

123. Feng, Y.; Shao, R.; Weijdegård, B.; Wang, T.; Johansson, J.; Sun, S.; Wang, W.; Egecioglu, E.; Billig, H.; Stener-Victorin, E. Effects of androgen and leptin on behavioral and cellular responses in female rats. Horm. Behav. 2011, 60, 427-438. [CrossRef]

124. Venancio, J.C.; Margatho, L.O.; Rorato, R.; Rosales, R.R.C.; Debarba, L.K.; Coletti, R.; Antunes-Rodrigues, J.; Elias, C.F.; Elias, L.L.K. Short-term high-fat diet increases leptin activation of CART neurons and advances puberty in female mice. Endocrinology 2017, 158, 3929-3942. [CrossRef] [PubMed]

125. Shutter, J.R.; Graham, M.; Kinsey, A.C.; Scully, S.; Lüthy, R.; Stark, K.L. Hypothalamic expression of ART, a novel gene related to agouti, is up-regulated in obese and diabetic mutant mice. Genes Dev. 1997, 11, 593-602. [CrossRef] [PubMed]

126. Padilla, S.L.; Qiu, J.; Nestor, C.C.; Zhang, C.; Smith, A.W.; Whiddon, B.B.; Rønnekleiv, O.K.; Kelly, M.J.; Palmiter, R.D. AgRP to Kiss1 neuron signaling links nutritional state and fertility. Proc. Natl. Acad. Sci. USA 2017, 114, 2413-2418. [CrossRef] [PubMed]

127. Luque, R.M.; Kineman, R.D.; Tena-Sempere, M. Regulation of hypothalamic expression of KiSS-1 and GPR54 genes by metabolic factors: Analyses using mouse models and a cell line. Endocrinology 2007, 148, 4601-4611. [CrossRef] [PubMed]

128. Topaloglu, A.K.; Reimann, F.; Guclu, M.; Yalin, A.S.; Kotan, L.D.; Porter, K.M.; Serin, A.; Mungan, N.O.; Cook, J.R.; Ozbek, M.N.; et al. TAC3 and TACR3 mutations in familial hypogonadotropic hypogonadism reveal a key role for neurokinin b in the central control of reproduction. Nat. Genet. 2009, 41, 354-358. [CrossRef] 
129. Min, L.; Adeola, O.; Carroll, R.S.; Kaiser, U.B. Glutamate acts as a cofactor in the activation of KISS1R by kisspeptin. In Signaling Originating from Membrane Receptors; Endocrine Society: San Francisco, CA, USA, 2013; Volume 3, p. SUN-402.

130. Lehman, M.N.; Merkley, C.M.; Coolen, L.M.; Goodman, R.L. Anatomy of the kisspeptin neural network in mammals. Brain Res. 2010, 1364, 90-102. [CrossRef] [PubMed]

131. Araujo-Lopes, R.; Crampton, J.R.; Aquino, N.S.; Miranda, R.M.; Kokay, I.C.; Reis, A.M.; Franci, C.R.; Grattan, D.R.; Szawka, R.E. Prolactin regulates kisspeptin neurons in the arcuate nucleus to suppress LH secretion in female rats. Endocrinology 2014, 155, 1010-1020. [CrossRef]

132. Moenter, S.M.; Chu, Z.; Christian, C.A. Neurobiological mechanisms underlying oestradiol negative and positive feedback regulation of gonadotrophin-releasing hormone neurones. J. Neuroendocrinol. 2009, 21, 327-333. [CrossRef]

133. Ciechanowska, M.; Łapot, M.; Malewski, T.; Mateusiak, K.; Misztal, T.; Przekop, F. Effects of GABAA receptor modulation on the expression of $\mathrm{GnRH}$ gene and $\mathrm{GnRH}$ receptor (GnRH-R) gene in the hypothalamus and GnRH-R gene in the anterior pituitary gland of follicular-phase ewes. Anim. Reprod. Sci. 2009, 111, 235-248. [CrossRef]

134. Pielecka-Fortuna, J.; Moenter, S.M. Kisspeptin increases $\gamma$-Aminobutyric acidergic and glutamatergic transmission directly to gonadotropin-releasing hormone neurons in an estradiol-dependent manner. Endocrinology 2010, 151, 291-300. [CrossRef]

135. Herbison, A.E.; Moenter, S.M. Depolarising and hyperpolarising actions of GABAA receptor activation on gonadotrophin-releasing hormone neurones: Towards an emerging consensus. J. Neuroendocrinol. 2011, 23, 557-569. [CrossRef] [PubMed]

136. Spruston, N.; McBain, C.J. Structural and functional properties of hippocampal neurons. In The Hippocampus Book; Andersen, P., Morris, R., Amaral, D., Bliss, T., O’Keefe, J., Eds.; Oxford University Press: New York, NY, USA, 2006; pp. 1-852.

137. Fallah, H.P.; Tovo-Neto, A.; Yeung, E.C.; Nóbrega, R.H.; Habibi, H.R. Paracrine/Autocrine control of spermatogenesis by gonadotropin-inhibitory hormone. Mol. Cell. Endocrinol. 2019, 492, 110440. [CrossRef] [PubMed]

138. Bhattarai, J.P.; Roa, J.; Herbison, A.E.; Han, S.K. Serotonin acts through 5-HT1 and 5-HT2 receptors to exert biphasic actions on GnRH neuron excitability in the mouse. Endocrinology 2014, 155, 513-524. [CrossRef] [PubMed]

139. Wright, M.M.; McMaster, C.R. PC and PE synthesis: Mixed micellar analysis of the cholinephosphotransferase and ethanolaminephosphotransferase activities of human choline/ethanolamine phosphotransferase 1 (CEPT1). Lipids 2002, 37, 663-672. [CrossRef] [PubMed]

140. Zhang, P.; Reue, K. Lipin proteins and glycerolipid metabolism: Roles at the ER membrane and beyond. Biochim. Biophys. Acta-Biomembr. 2017, 1859, 1583-1595. [CrossRef]

141. Law, N.C.; Weck, J.; Kyriss, B.; Nilson, J.H.; Hunzicker-Dunn, M. Lhcgr expression in granulosa cells: Roles for PKA-phosphorylated $\beta$-catenin, TCF3, and FOXO1. Mol. Endocrinol. 2013, 27, 1295-1310. [CrossRef]

142. Palermo, R. Differential actions of FSH and LH during folliculogenesis. Reprod. Biomed. Online 2007, 15, 326-337. [CrossRef]

143. Ortiga-Carvalho, T.M.; Chiamolera, M.I.; Pazos-Moura, C.C.; Wondisford, F.E. Hypothalamus-pituitary-thyroid axis. Compr. Physiol. 2016, 6, 1387-1428. [CrossRef]

144. Gogakos, A.I.; Duncan-Bassett, J.H.; Williams, G.R. Thyroid and bone. Arch. Biochem. Biophys. 2010, 503, 129-136. [CrossRef]

145. Robbins, J. Thyroid hormone transport proteins and the physiology of hormone binding. In Werner and Ingbar's, The Thyroid, 8th Ed.; Braverman, L.E., Utiger, R.D., Eds.; Lippincott Williams \& Wilkins: Philadelphia, PA, USA, 2000; pp. 105-120.

146. Choksi, N.Y.; Jahnke, G.D.; St Hilaire, C.; Shelby, M. Role of thyroid hormones in human and laboratory animal reproductive health. Birth Defects Res. B Dev. Reprod. Toxicol. 2003, 68, 479-491. [CrossRef]

147. Silva, J.F.; Ocarino, N.M.; Serakides, R. Thyroid hormones and female reproduction. Biol. Reprod. 2018, 99, 907-921. [CrossRef] [PubMed]

148. Castañeda, D.C.; Langlois, V.S.; Fernandino, J.I. Crossover of the hypothalamic pituitary-adrenal/interrenal,-thyroid, and -gonadal axes in testicular development. Front. Endocrinol. 2014, 5, 1-11. [CrossRef] 
149. Dutt, M.; Wehrle, C.J.; Jialal, I. Physiology, Adrenal Gland. In StatPearls. Treasure Island (FL): StatPearls. Available online: https://www.ncbi.nlm.nih.gov/books/NBK537260/ (accessed on 18 July 2020).

150. Majzoub, J.A. Corticotropin-releasing hormone physiology. Eur. J. Endocrinol. Suppl. 2006, 155, 71-76. [CrossRef]

151. Chen, M.D.; O’Byrne, K.T.; Chiappini, S.E.; Hotchkiss, J.; Knobil, E. Hypoglycemic 'stress' and gonadotropin-releasing hormone pulse generator activity in the rhesus monkey: Role of the ovary. Neuroendocrinology 1992, 56, 666-673. [CrossRef] [PubMed]

152. Yates, R.; Katugampola, H.; Cavlan, D.; Cogger, K.; Meimaridou, E.; Hughes, C.; Metherell, L.; Guasti, L.; King, P. Adrenocortical development, maintenance, and disease. In Current Topics in Developmental Biology, 1st Ed.; Thomas, P., Ed.; Elsevier: London, UK, 2013; Volume 106, pp. 239-312.

153. Whirledge, S.; Cidlowski, J.A. Glucocorticoids, stress, and fertility. Minerva Endocrinol. 2010, 35, $109-125$.

154. Kalantaridou, S.N.; Zoumakis, E.; Makrigiannakis, A.; Lavasidis, L.G.; Vrekoussis, T.; Chrousos, G.P. Corticotropin-releasing hormone, stress and human reproduction: An Update. J. Reprod. Immunol. 2010, 85, 33-39. [CrossRef] [PubMed]

155. Oyola, M.G.; Handa, R.J. Hypothalamic-pituitary-adrenal and hypothalamic-pituitary-gonadal axes: Sex differences in regulation of stress responsivity. Stress 2017, 20, 476-494. [CrossRef]

156. Hassani-Nezhad-Gashti, F.; Kummu, O.; Karpale, M.; Rysä, J.; Hakkola, J. Nutritional status modifies pregnane $X$ receptor regulated transcriptome. Sci. Rep. 2019, 9, 1-13. [CrossRef] [PubMed]

157. Zhai, Y.; Pai, H.V.; Zhou, J.; Amico, J.A.; Vollmer, R.R.; Xie, W. Activation of pregnane X receptor disrupts glucocorticoid and mineralocorticoid homeostasis. Mol. Endocrinol. 2007, 21, 138-147. [CrossRef]

158. Tokarz, V.L.; MacDonald, P.E.; Klip, A. The cell biology of systemic insulin function. J. Cell Biol. 2018, 217, 1-17. [CrossRef]

159. Starup-Linde, J.; Gregersen, S.; Frost, M.; Vestergaard, P. Use of glucose-lowering drugs and risk of fracture in patients with type 2 diabetes. Bone 2017, 95, 136-142. [CrossRef] [PubMed]

160. Ducy, P.; Desbois, C.; Boyce, B.; Pinero, G.; Story, B.; Dunstan, C.; Smith, E.; Bonadio, J.; Goldstein, S.; Gundberg, C.; et al. Increased bone formation in osteocalcin-deficient mice. Nature 1996, 382, 448-452. [CrossRef] [PubMed]

161. Sunnerhagen, M.; Drakenberg, T.; Forsen, S.; Stenflo, J. Effect of $\mathrm{Ca}^{2+}$ on the structure of vitamin K-dependent coagulation factors. Haemostasis 1996, 26, 45-53. [CrossRef] [PubMed]

162. Tangseefa, P.; Martin, S.K.; Fitter, S.; Baldock, P.A.; Proud, C.G.; Zannettino, A.C.W. Osteocalcin-dependent regulation of glucose metabolism and fertility: Skeletal implications for the development of insulin resistance. J. Cell. Physiol. 2018, 233, 3769-3783. [CrossRef]

163. Oury, F.; Sumara, G.; Sumara, O.; Ferron, M.; Chang, H.; Smith, C.E.; Hermo, L.; Suarez, S.; Roth, B.L.; Ducy, P.; et al. Endocrine regulation of male fertility by the skeleton. Cell 2011, 144, 796-809. [CrossRef] [PubMed]

164. Oury, F.; Ferron, M.; Huizhen, W.; Confavreux, C.; Xu, L.; Lacombe, J.; Srinivas, P.; Chamouni, A.; Lugani, F.; Lejeune, H.; et al. Osteocalcin regulates murine and human fertility through a pancreas-bone-testis axis. J. Clin. Investig. 2013, 123, 2421-2433. [CrossRef] [PubMed]

165. De Toni, L.; Guidolin, D.; De Filippis, V.; Peterle, D.; Rocca, M.S.; Di Nisio, A.; De Rocco Ponce, M.; Foresta, C. SHBG141-161 domain-peptide stimulates GPRC6A-mediated response in leydig and $\beta$-Langerhans cell lines. Sci. Rep. 2019, 9, 1-11. [CrossRef]

166. Rossi, M.; Battafarano, G.; Pepe, J.; Minisola, S.; Del Fattore, A. The endocrine function of osteocalcin regulated by bone resorption: A lesson from reduced and increased bone mass diseases. Int. J. Mol. Sci. 2019, 20, 4502. [CrossRef]

167. Coskun, G.; Sencar, L.; Tuli, A.; Saker, D.; Alparslan, M.M.; Polat, S.; Silvestrini, A. Effects of osteocalcin on synthesis of testosterone and INSL3 during adult leydig cell differentiation. Int. J. Endocrinol. 2019, 2019, 1-18. [CrossRef]

168. Spruiell, K.; Gyamfi, A.A.; Yeyeodu, S.T.; Richardson, R.M.; Gonzalez, F.J.; Gyamfi, M.A. Pregnane X receptor-humanized mice recapitulate gender differences in ethanol metabolism but not hepatotoxicity. J. Pharmacol. Exp. Ther. 2015, 354, 459-470. [CrossRef]

169. Taborska, E.; Pasulka, J.; Malik, R.; Horvat, F.; Jenickova, I.; Matošević, Z.J.; Svoboda, P. Restricted and non-essential redundancy of RNAi and PiRNA pathways in mouse oocytes. PLoS Genet. 2019, 15, 1-22. [CrossRef] 
170. Wang, J.H.; Li, Y.; Deng, S.L.; Liu, Y.X.; Lian, Z.X.; Yu, K. Recent research advances in mitosis during mammalian gametogenesis. Cells 2019, 8, 567. [CrossRef]

171. Skaftnesmo, K.O.; Edvardsen, R.B.; Furmanek, T.; Crespo, D.; Andersson, E.; Kleppe, L.; Taranger, G.L.; Bogerd, J.; Schulz, R.W.; Wargelius, A. Integrative testis transcriptome analysis reveals differentially expressed miRNAs and their mRNA targets during early puberty in Atlantic salmon. BMC Genom. 2017, 18, 1-12. [CrossRef] [PubMed]

172. Salas-Huetos, A.; James, E.R.; Aston, K.I.; Jenkins, T.G.; Carrell, D.T. Diet and sperm quality: Nutrients, foods and dietary patterns. Reprod. Biol. 2019, 19, 219-224. [CrossRef]

173. Tong, M.H.; Mitchell, D.; Evanoff, R.; Griswold, M.D. Expression of Mirlet7 family microRNAs in response to retinoic acid-induced spermatogonial differentiation in mice. Biol. Reprod. 2011, 85, 189-197. [CrossRef]

174. Huszar, J.M.; Payne, C.J. MicroRNA 146 (Mir146) modulates spermatogonial differentiation by retinoic acid in mice. Biol. Reprod. 2013, 15, 1-10. [CrossRef]

175. Lanham, S.A.; Cagampang, F.R.; Oreffo, R.O.C. Maternal high fat diet and offspring expression levels of vitamin K-dependent proteins. Endocrinology 2014, 155, 4749-4761. [CrossRef] [PubMed]

(C) 2020 by the authors. Licensee MDPI, Basel, Switzerland. This article is an open access article distributed under the terms and conditions of the Creative Commons Attribution (CC BY) license (http://creativecommons.org/licenses/by/4.0/). 